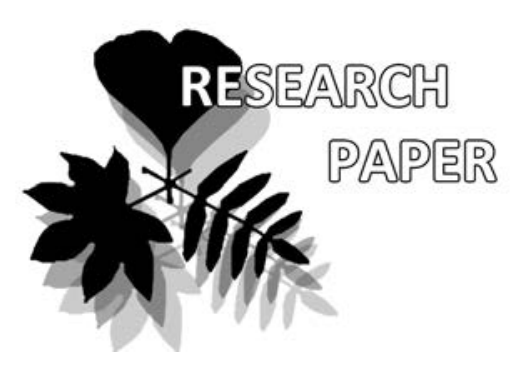

\title{
Distribution pattern of seven Polytrichum species in the East European Plain and Eastern Fennoscandia
}

\author{
Sergey Yu. Popov
}

Sergey Yu. Popov

e-mail: sergei.popov.2015@yandex.ru

Lomonosov Moscow State University, Biological Faculty, Moscow, Russia

Manuscript received: 29.03.2018

Review completed: 25.04 .2018

Accepted for publication: 07.05 .2018

Published online: 08.05.2018

\begin{abstract}
A B S T R A C T
Distribution of seven species of the genus Polytrichum (P. commune, P. byperboreum, P. jensenii, P. juniperinum, P. piliferum, $P$. strictum and $P$. swartzii) on the territory of the East European Plain and Eastern Fennoscandia (EEPEF) was studied. For each species, model maps of distribution ranges were constructed and the causes that determine the pattern of species are considered. Distribution of most species correlates to a high degree with spatial changes in the amount of precipitation, relative humidity and monthly temperature averages during the vegetative season. However, $P$. piliferum is an exception to this rule, as its distribution is influenced not only by climate, but also by location of fluvioglacial deposits on the territory of EEPEF. Distribution range of $P$. hyperboreum and P. jensenii is mainly limited by Subarctic region (Tundra and Forest-Tundra), and this range looks diminishing.

Ke yw ord s: Polytrichum, kriging-method, distribution range, Biogeography, climatic optimum, arealogical analysis, BIOCLIM
\end{abstract}

\section{P E 3 Ю M E}

Попов С.Ю. Закономерности распространения семи видов рода Polytrichum на территории Восточно-Европейской равнины и восточной Фенноскандии. Изучено распространение семи видов рода Polytrichum (P. commune, P. hyperboreum, P. jensenii, P. juniperinum, P. piliferum, P. strictum и P. swartzii) на территории Восточно-Европейской равнины и Восточной Фенноскандии (ВЕРВФ). А^я каждого вида построены модельные карты ареалов и рассмотрены причины, обуславливающие рисунок ареалов вилов. Распространение большинства видов высоко коррелирует с изменением количества осадков, относительной влажности воздуха и среднемесячных температур вегетационного периода. ОАнако, P. piliferum является искцючением из этого правила, поскольку его распространение обуслов ено не только климатом, но распространением флювиогляциальных отложений на территории ВЕРВФ. Распространение P. byperboreum и $P$. јеnsenï связано преимущественно с северными регионами - тундрой и месотундрой, а их ареалы имеют рисунок сокращающихся.

КАючевые слова: Polytrichum, кригинг, ареал, биогеография, климатический оптимум, ареалогический анализ, BIOCLIM
At present, as the floras of most regions are very well studied and due to development of GIS, biogeography raises the question of establishing the boundaries of individual taxa and biogeographic regions on quantitative basis with the help of statistical methods (Mateo et al. 2011). At the present stage of the development of bryology, the bryophytes of various regions are well studied. Studies of local and regional bryofloras conducted by different researchers starting from the late 20th century produce almost complete inventory of the bryoflora on such a large territory as the East European Plain and Eastern Fennoscandia (EEPEF). Therefore, the task of generalizing these materials, of visualizing them on maps, and of establishing the biogeographical patterns of the species' distribution and the species' diversity is extremely topical. Spatial distribution of species depends on many factors. At the local (regional) level, it is determined by the habitat parameters (Clymo 1982, Maksimov 1982, Gignac \& Vitt 1990, Gignac et al. 1991, Hájková \& Hájek 2007, Wojtun 2013, Popov \& Fedosov 2017, Smagin et al. 2017 and many others). At a more global level (interregional and subcontinental, i.e. covering several natural zones), climate exerts the dominant influence on species' distribution (Woodwart 1987) and the main climatic factors of species' distribution, i.e. monthly and annual temperature averages, precipitation, humidity and others, might be considered as leading (Gignac \& Vitt 1990, Gignac et al. 1991, Melosik 2006, Séneca \& Söderström 2008, Popov 2016).

Of course, these above mentioned two approaches have a different format, which is due to the fact that the scope of examination is different. Thus, at the local level one can study the biotopic distribution. While at the interregional level the biotopic distribution is invisible because of the smaller scale, and we consider the species' occurrence in the local floras of the region. At this case the species' distributional range is compiled from the set of local floras. Thus, 
considering the distribution of the species in large areas on a smaller scale, we have to abandon the study of its biotopic distribution and the study of ecological factors affecting the species' coenotic distribution. In this case, we turn to arealogical analysis and to studying the biogeographical patterns of species' distribution. The traditional task of biogeography is to identify the boundaries of the species' ranges and to find patterns of species' distribution determined by geographical, biotic and climatic factors (Tolmachev 1974). In biogeography, the ecological aspect of the analysis of the species' distribution is most often associated with the concept of an ecological niche as it was defined by Grinnel (1917), i.e. the response of a species to spatial changes in environmental parameters. In contrast to the ecological niche as defined by Hutchinson (1965) (which is determined by the properties of species in the hyperspace of environmental factors, i.e. the species' own properties, and not these of the environment), the Grinnel's niche is attached to environmental parameters, which alteration determines the species' distribution. Therefore, comparing, for example, the climatic factors and the species' quantitative characteristics in a certain space, it is possible to identify the species' climatic optimum and pessimum. So far, the problem of analyzing the species' range has been mostly is solved with vascular plants and animals, in order to establish the boundaries of natural zones and to map the species' diversity (Kurnaev 1973, Tolmachev 1974, Schmidt 1979, Danilenko \& Rumyantsev 2000, Ignatov 1993, Kier et al. 2005, Krestov et al. 2006).

At present, the task of creating a species' distributional range is done with the help of computer simulation methods (Mateo et al. 2011). The model's verity and reliability depend on the choice of predictors and on the modeling method, scale, ways of interaction between environmental and geographic factors and the extrapolation method used.

The maximum entropy method is now increasingly used in mathematical modeling of species' ranges (Sergioa 2005, Phillips et al. 2006, Puzachenko et al. 2011, Mateo et al. 2013). This method allows building a model of species' ranges with the use of binary data (presence-absence). However, a model map based on binary data allows us only to estimate the boundaries of the range as a whole. The species' quantitative characteristics within the range (such as occurrence and abundance) can not be considered.

Another commonly used method for compiling a species' range is dot mapping based on the herbarium data (for example, GBIF, Ivanov et al. 2017). This method has evident superiority in accuracy and reliability in installing the points, but it can not guarantee the completeness of coverage - simply because no territory sufficiently large can be explored in full, and certainty of data for those places, where herbarium specimens have not been collected, will always remain a question (Mateo et al. 2011). Moreover, this method is extremely time-consuming, and it takes a lot of time to identify the species' location points. As a rule, dot mapping gives us an objective picture of what we know about the species' distribution of, but not of the species' actual distribution. Such method of mapping can take dozens of years (Lahti \& Lampinen 1999). However, despite the limitations that the species' presence data have, actually the vast majority of studies are based on this type of data, since the data on the species' absence are simply lacking.

The simplest method for studying floristic diversity is Zonal Statistics (Ignatov 1993, Geffert et al. 2013, Pisarenko \& Bakalin 2017). This method allows using statistical indicators (average, minimum, maximum, etc.) for individual regions already mapped. Thus, statistics for administrative regions or ecoregions can be used. It is clear that this method permits us only to identify general trends, without drawing natural boundaries of species' range. In addition, when using Zonal Statistics, one needs to recalculate the number of species per area - since the compared regions can vary in area quite widely (Arrehnius 1921).

There are also a large number of quantitative methods for creating spatial models for species or species' diversity that are based on multidimensional statistics. When creating such models, we choose climatic and non-climatic (relief, soil, etc.) factors as independent variables, and the presence / absence (or quantitative characteristics) of species or the number of species at the point studied - as depended ones (Phillips et al. 2006). Paradoxically, when generating models of species distribution by methods of multidimensional techniques, which result in a map, the spatial relationships between the points are not considered, since each point's coordinates are used exclusively to extract the values of independent variables at that point, without taking into account what is happening around. The fact is that the multidimensional statistics methods estimate the value of a particular point with no regard to the neighboring points' values. Possible spatial correlation between the independent variables is also not taken into account. Therefore, in my opinion, these methods are more suitable for creating maps of potential distribution (based on predictors' values) than for creating maps of the species' real distribution (based on an independent basis).

Whichever method of mapping is used, a critical evaluation of the data's reliability on individual locations has great importance. As a rule, one has to rely on a large amount of data available in the literature. Often one cannot be absolutely confident in the correctness of the species' definition.

Geostatistics can help us to overcome all these problems. Geostatistical methods are based on interpolation of quantitative data obtained during field studies in an irregular network of points, and transforming it into a regular grid of pixels. In other words, when an irregular network of values is turned into a regular one, the data fill all the points where measurements have not been made. This can be realized with the help of kriging-method (Demyanov \& Savelieva 2010, Lurie 2010, Saveliev et al. 2012), which is based on regression equations, where the comparative weights of points (by distance from each other), correlations between points and variance are also considered. Among all methods of Geostatistics, the kriging-method is the most powerful, since it permits 1) to establish a general trend of the values' changes in space (deterministic variation), 2) to make visible autocorrelation, and 3) to cut off possible noises, and to compile on this basis a statistically significant coverage (Demyanov \& Savelieva 2010, Lurie 2010, Saveliev 
et al. 2012). Finally, methods of geostatistics (in contrast to the multivariate analysis) permit to consider spatial correlation between points based on their weights. Therefore, even when there are no data for a space between two points with known values, the kriging method permits to interpolate possible deviations from the general trend.

Currently, geostatistical methods are extensively used in such areas of science, as environmental science (air pollution maps), climatology and meteorology (temperature distribution maps, precipitation distribution, and so on), geodesy and cartography (Digital Elevation Model) (Demyanov \& Saveliev 2010, Lurie 2010). However, these methods have not been used yet in biogeography to study the species' distribution. Perhaps this can be explained by the territories' insufficient exploration (a sufficient number of points is required to create a valid continuous coverage).

The East European Plain, with its vast lowland territory, can be used as a model area for studying regularities of the species' distribution caused by climatic variables. For the last 30-40 years a lot of local moss flora lists within this area have been published. Thus now it seems to be possible to compile maps of individual species' ranges based on this data. In addition, WORLDCLIM / BIOCLIM climate database (Hijmans et al. 2005) was made available to the public recently, and it provides suitable climatic data to study the species' spatial distribution patterns in the climatic context.

Previously, I have already analyzed the distribution of some species of the Sphagnum genus using geostatistics methods (Popov 2016). The methodology for creating model maps of species' ranges is adapted to the goals of biogeography (Popov 2017). For the present work, we have chosen as the objects of study seven species of the genus Polytrichum, related to sections Polytrichum and Juniperina (Polytrichum commune, P. byperboreum, P. jensenii, P. juniperinum, P. piliferum, P. strictum и P. swartzii) (Ignatov 2017). The goal of this work is to compile and to visualize a distributional ranges model for these species and to analyze the patterns of their distribution. Since the scale we use is too small to regard the species' biotopic distribution, and only the species' presence in local floras and its occurrence over the territory is considered, the hypothesis that the climatic factors have primary influence on the species' distribution has been taken as the basic one. In addition, we also compared the patterns of the species' areas with the boundaries of natural zones (Ahti et al. 1968, Kurnaev 1973) and the contours of a landscape map (Isachenko 1988).

\section{MATERIALAND METHODS}

In order to study distribution of species of the genus Polytribum on the EEPEF, we analyzed publications, which contain annotated lists of local bryofloras in different regions (European part of the Russian Federation, the Baltic States, Belarus, Moldova, Ukraine and Finland). The annotated lists usually note the geographical coordinates of the area studied and of the species' occurrence. All these data were compiled into a relational database created with the help of MS Access. The moss collection points were superimposed on the EEPEF map following the geographic coordinates (see Fig. 1). The species' occurrence in diffe rent lists is estimated either by number of herbarium specimens of each species, or by number of records made by the collector, or by collector's general impression. Taking all this in account, for compiling our database, we assessed each species' occurrence by a six-point scale:

$\mathbf{0}$ - species absent,

$1-1-2$ records (very rare),

$2-3-7$ records (rare),

3 - more than 7 records, but not everywhere (sporadic),

4 - frequent, but not always present in suitable habitats (frequent),

5 - common and always present in suitable habitats (common).

Data on the occurrence were taken from the articles of different authors, cited in the caption to Fig. 1. In addition, in order to correct old and erroneous data, the latest issue of Moss flora of Russia (Ignatov 2017) and the Global Biodiversity Information Facility (http://www.gbif.org/) were used, as these sources provide information on availability of herbarium material for each species in different regions of EEPEF.

According to the scale described above, continuous coverage for each species was established using the kriging method (Demyanov \& Savelyeva 2010) with a resolution of $10 \mathrm{~km}$ per 1 pixel. Validation of continuous coverage was carried out by cross-validation method with the SAGA GIS software. Geostatistics uses the coefficient of determination $\left(\mathrm{R}^{2}\right)$ as the index of cross-validation quality (Demyanov \& Savelyeva 2010). The values of this indicator for continuous coverage of all species studied vary from 0.972 to 0.995 (Fig. 3 and 4). Methods of geostatistics used for creating and verifying continuous coverage, have already been described in literature (Demyanov \& Savelyeva 2010, Savelyev et al. 2012). Methods for creating maps of the moss species' distribution based on a point layer were described in details in a previous publication (Popov 2017). In total, a sample of 177 points was used to create continuous coverage (see Fig. 1).

To analyze the dependence of the species' distribution on climatic factors, the variables recommended for studying distribution of biological objects within the programs WORLDCLIM and BIOCLIM (BIOCLIM project 2009) were chosen. A total of 43 climatic variables were included in the analysis (see Table 1). The authors of the WORLDCLIM program calculated these variables having compiled information from the world network of meteorological stations (Hijmans et al. 2005). For each variable of the BIOCLIM database, continuous grid coverages with a resolution of $10 \mathrm{~km}$ per 1 pixel were created.

Continuous coverages of the species' occurrence were rearranged in the ArcGis program with the help of the "natural breaks" method (Lurye 2010, Popov 2013) into integer ones for mapping species' distribution. In addition, the species' distribution was compared with the boundaries of vegetation zones, which in the present work are given after Ahti et al. 1968, Kurnayev 1973 (see Fig. 1).

Each GRID coverage was composed in Azimuthal Equidistant Projection (central meridian $45^{\circ} \mathrm{E}$, chief parallel $-55^{\circ} \mathrm{N}$ ). In total there were compiled 43 grid coverages for BIOCLIM data, and 8 - for the occurrence of 


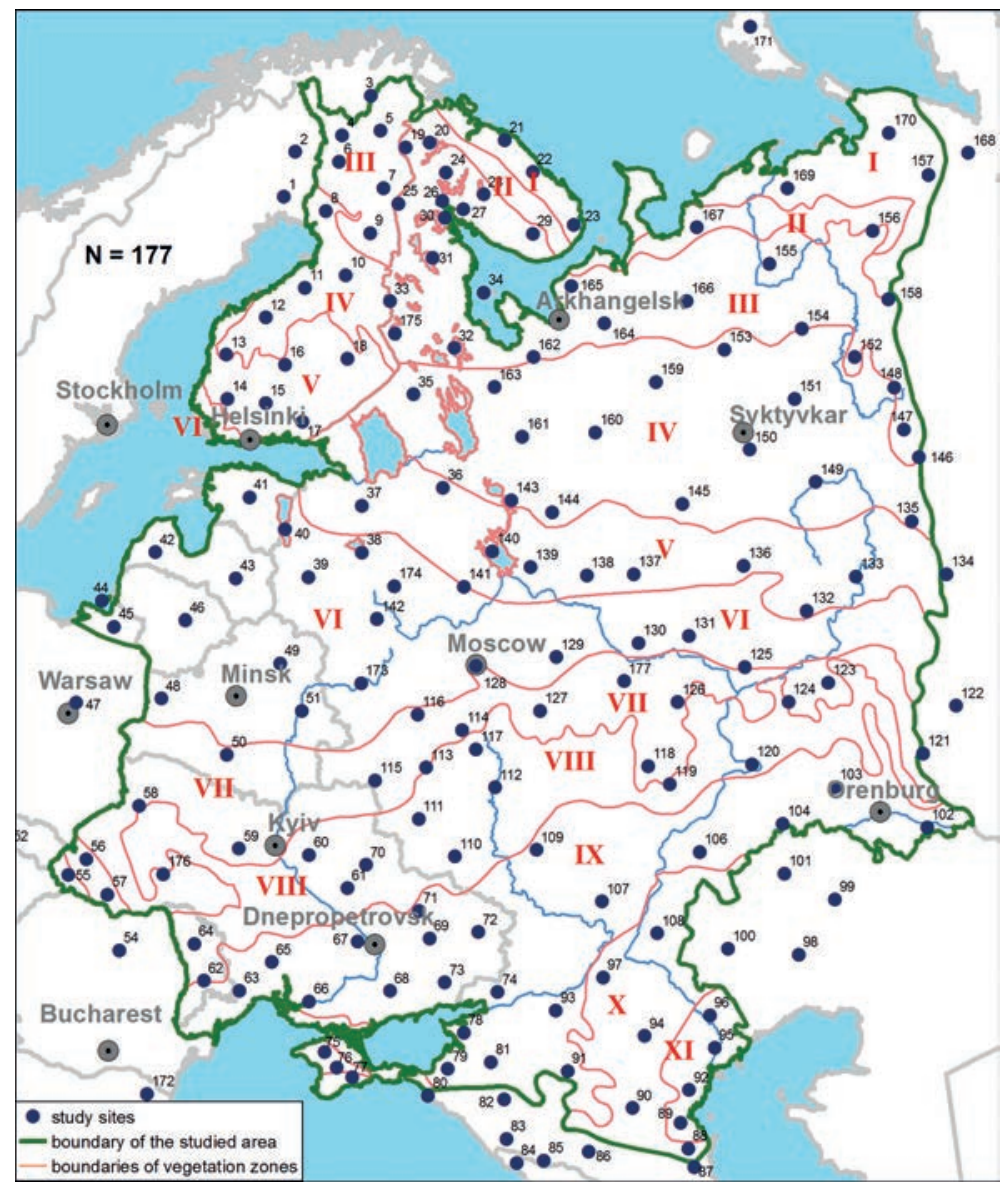

Figure 1 Study area, showing localities involved in analysis and vegetation zones: I - Tundra; II - Forest-Tundra; III - Nothern Taiga; IV - Middle Taiga; V southern taiga; VI - Hemiboreal Forests; VII - Broadleaved Forests; VIII - Forest-Steppe; IX - Steppe; X - Semidesert; XI - Desert. Study sites: 1-18 - Söderström 1998; 19 - Belkina \& Likhachev 2004; 20 - Likhachev \& Belkina 1999; 21-23 - Shlyakov \& Konstantinova 1982; 24 - Belkina \& Likhachev 2010; 25 - Drugova et al. 2017; 26 - Belkina \& Likhachev 1997; 27-29 - Shlyakov \& Konstantinova 1982; 30 - Bogdanova 1981; 31-32 - Abramov \& Volkova 1998; 33 - Boichuk 2001; 34 - Churakova 2002; 35 - Boichuk 2002; 36-39 - Kurbatova 2002; 40 - Andreeva \& Filip'eva 2005; 41 - Vellak et al. 2015; 42-43 - Abolin 1968; 44 - Dolnik \& Napreenko 2007; 45 - Söderström 1998; 46 - Strazdina et al. 2011; Söderström 1998; 47 - Stebel 2012; 48-51 - Rykovsky \& Maslovsky 2009; 52 - Dite et al. 2007; 53 - Papp et al. 2010; 54 - Erzberger et al. 2012; 55-57 - Zerov \& Partyka 1975; 58-59 - Lazarenko 1955; 60-61 - Gapon 1997; 62-64 - Simonov 1978; 65-69 - Boiko 2009; 70-72 - Popova 2002; 73-74 - Sereda \& Ignatov 2008; 75-77 - Partyka 2005; 78-80 - Ignatova et al. 2005; 81 - Doroshina 2011; 82 - Akatova \& Ignatova 2015; 83 - Akatova 2002; 84 - Doroshina 2015; 85 - Ignatova et al. 2008; 86 - Kharzinov et al. 2004; 87 - Abakarova et al. 2015; 88 - Ignatov et al. 2010; 89-92 - Doroshina 2011; 93-96 - Suragina et al. 2002; 97 - Suragina 2001; 98-105 - Spirina \& Zolotov 2004; 106-108 - Suragina 2001; 109-115 - Popova 2002; 116 - Teleganova 2008; 117 - Popova et al. 2015; 118 Serebryakova 2009; 119 - Doroshina-Ukrainskaya 1999; 120 - Popov 2000; 121 - Zolotov \& Baisheva 2003; 122 - Baisheva et al. 2015; 123-124 - Ariskina 1978; 125 - Ignatov et al. 2005; 126 - Popov et al. 2001; 127 - Volosnova et al. 2000; 128 - Ignatov et al. 2011; 129-130 - Popov et al. 2004; 131 - Czernjadieva 2001a; Czernjadieva et al. 2013; 132 - Rubtsova 2005; 133 - Bezgodov 2002; 134 - Dyachenko et al. 1996; 135 - Ignatova et al. 1995; 136 - Zheleznova 2014; 137-138 - Fedosov \& Popov 2004; 139-140 - Volkova et al. 1994; 141 - Notov et al. 2002; 142 - Ignatov et al. 1998; 143 - Karnazina 2013; 144 - Filippov \& Boichuk 2015; 145 - Zheleznova 2014; 146 - Djachenko \& Djachenko 2010; 147 - Ignatova et al. 1996; 148 - Zheleznova \& Shubina 1997; 149-158 - Zheleznova 1994; 159-162 - Churakova 2002; 163 - Boichuk et al. 2002; 164-166 - Ignatov et al. 2008.; Popov \& Buryanina 2012; 167 - Zheleznova \& Shubina 2015; 168 Czernyadjeva 1994; Czernyadjeva 2001; 169-171 - Afonina \& Czernyadjeva 1995; Czernyadjeva 2001b; 172 - Natcheva \& Ganeva 2005; 173 - Ignatov \& Ignatova 2003; 174 - Notov et al. 2002; 175 - Maksimov et al. 2009; 176 - Bolyukh 1995; 177 - Shestakova 2005 selected species and species number. All of them were combined into a single spatial coverage. This coverage was transformed into relation database consisting of 49557 rows (number of pixels) and 51 columns (7 species, 1 species number and 43 climatic factors) in ERDAS package. This database was subjected to correlation analysis with software Statistica 6.0. Creation and verification of coverages were performed with SAGA software. The intersection of the vector layers and calculation of areas were performed with ArcGis program.

\section{RESULTSAND DISCUSSION}

The general patterns of the spatial variation of climatic factors in the study area were set out by us earlier (Popov 2016). In brief, they consist in the fact that the western regions during the growing season are characterized by a much greater amount of precipitation than the central and eastern ones, which is due to the patterns of movement of Atlantic cyclones from west to east. As a result, such regions as the west of Ukraine and Belarus, the Baltic States, the North-West of Russia, Karelia and Finland are the most humid, especially during the autumn-summer period, i. e. in August-October. The distribution of summer temperatures is associated with zonal patterns of distribution of the solar insolation. In addition, humidification of some regions is increased due to the presence of large bodies of water (Alisov 1956) (see Fig. 2).

Table 1. Variables used in the analysis from the database BIOCLIM

\begin{tabular}{|c|c|}
\hline Codes & Explanations \\
\hline $\operatorname{tm} 01-12$ & $\begin{array}{l}\text { Monthly temperature, }{ }^{\circ} \mathrm{C} \text { (January } \\
\text { to December) }\end{array}$ \\
\hline pr 01-12 & $\begin{array}{l}\text { Monthly precipitation, } \mathrm{mm} \\
\text { (January to December) }\end{array}$ \\
\hline reh 04-10 & $\begin{array}{l}\text { Relative humidity, \% (April to } \\
\text { October) }\end{array}$ \\
\hline pr_a & Annual precipitation, $\mathrm{mm}$ \\
\hline amt & Annual Mean Temperature \\
\hline pr_wtm & Precipitation of Wettest Month \\
\hline pr_drm & Precipitation of Driest Month \\
\hline pr_wtq & Precipitation of Wettest Quarter \\
\hline pr_drq & Precipitation of Driest Quarter \\
\hline pr_wmq & Precipitation of Warmest Quarter \\
\hline pr_clq & Precipitation of Coldest Quarter \\
\hline t_wtq & $\begin{array}{l}\text { Mean Temperature of Wettest } \\
\text { Quarter }\end{array}$ \\
\hline t_drq & $\begin{array}{l}\text { Mean Temperature of Driest } \\
\text { Quarter }\end{array}$ \\
\hline t_wmq & $\begin{array}{l}\text { Mean Temperature of Warmest } \\
\text { Quarter }\end{array}$ \\
\hline t_clq & $\begin{array}{l}\text { Mean Temperature of Coldest } \\
\text { Quarter }\end{array}$ \\
\hline
\end{tabular}



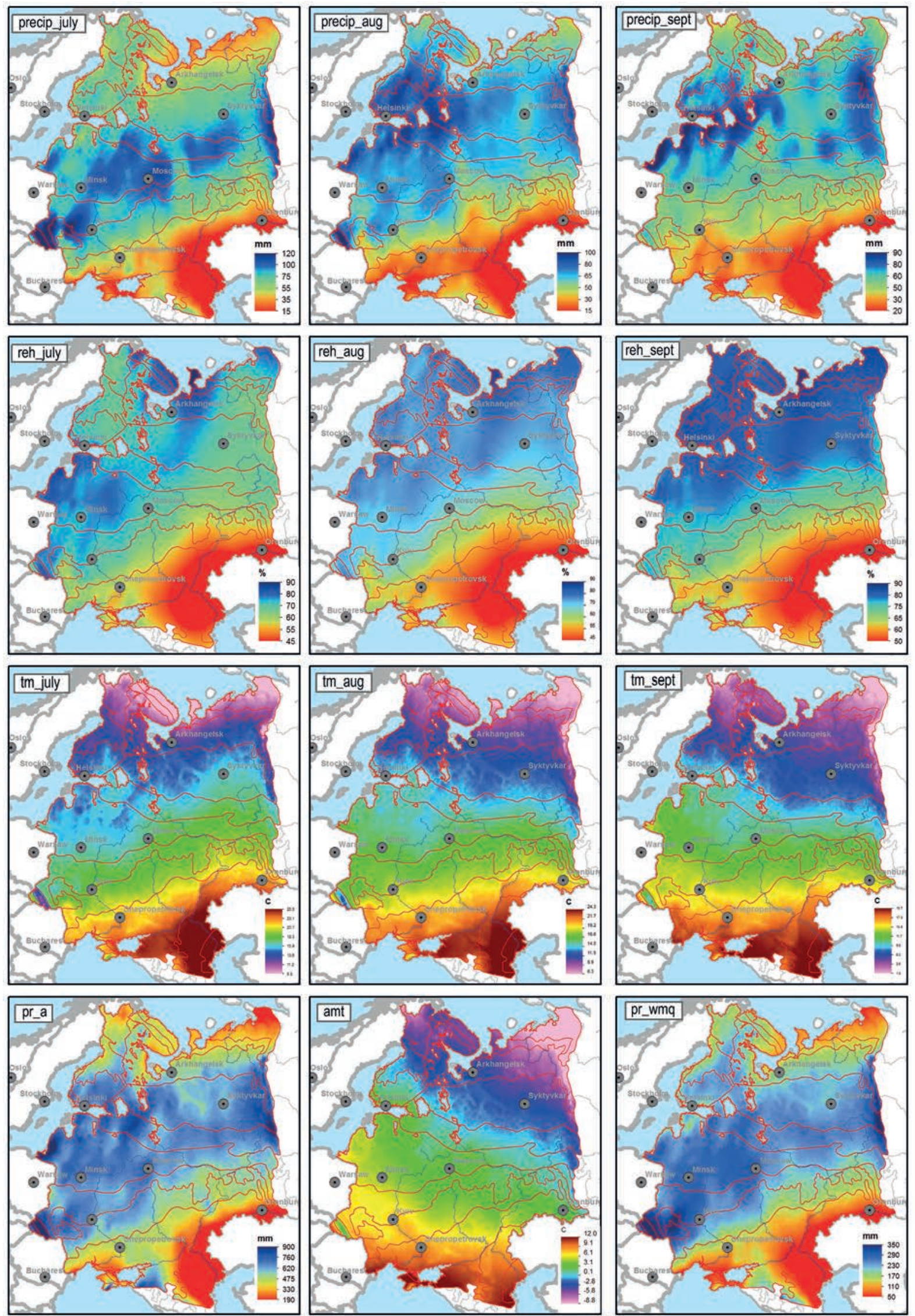

Figure 2 The distribution of the most important climatic variables on the territory of the East European Plain and Eastern Fennoscandia: precip_july...sept - summ of precipitation of August-September; reh_july...sept - relation humidity of AugustSeptember. tm_july...sept - monthly temperature of August-September; pr_a - annual precipitation; amt - mean annual precipitation; pr_wmq - precipitation of Warmest Quarter. The red lines show the boundaries of the vegetation zones 
The model maps of the distribution ranges for the species studied are shown on Fig. 3.

Polytrichum commune. The results of modeling this species' range show that the species is widely distributed in the territory of EEPEF. It grows in all vegetation zones (see Fig. 3, Table 2). The maximum occurrence (com) is observed in the Forest zone and in the Tundra and ForestTundra zones of Polar Urals (Fig. 3). Area of the com zone makes more than half of the total area of EEPEF - 52.2\% (see Table 2). To the north and to the south of the Forest zone, the occurrence of $P$. commune is gradually decreasing (see Fig. 3, Table 2). This species becomes rare and very rare in the south starting with the Steppe zone. In Forest-Steppe and Broad-Leaved Forests zones its abundance varies from $\boldsymbol{v} \boldsymbol{r}$ to $\boldsymbol{f r}$. Summarily, this species' area covers $94.3 \%$ of the total area of EEPEF (see Table 2).

Polytrichum strictum. This species' area covers all the vegetation zones, except the Desert zone (see Fig. 3, Table 3). The species has the highest occurrence in the Tundra and Forest-Tundra zones - and not in the Forest zone, as P. commune. Area of the com zone is small - only $6.3 \%$ of the total area of EEPEF. This is due to the fact that Tundra and Forest-Tundra zones cover rather a small part of the territory of EEPEF (see Table 3). However, P. strictum is also quite frequent in the Forest zone. Area of the zone $\boldsymbol{f r}$ of this species makes $55.5 \%$ of the total area of EEPEF. The $\boldsymbol{f r}$ and $\mathbf{c o m}$ zones together make $61.8 \%$ of the total area (see Table 3). P. strictum gradually disappears from the cover to the south of the Forest zone (see Fig. 3, Table 3). In the Steppe and the Semidesert zones this species is rare or very rare. In different regions in the southern part of the Forest zone and in the Forest-Steppe, its abundance varies from $\boldsymbol{v} \boldsymbol{r}$ to $\boldsymbol{f r}$ (see Table 3). Summarily, the P. strictum area occupies $81.2 \%$ of the total area of EEPEF.

Polytrichum juniperinum. This species occures in all vegetation zones, but does not reach high occurrence (com) anywhere. However, from the Tundra, throughout the Forest zone and even slightly to the south, this species occurs quite often (fr) (Fig. 3, Table 4). In the zones of Deciduous forests, Forest-Steppe and Steppe, the abundance of $P$. juniperinum varies from $\boldsymbol{r}$ to $\boldsymbol{f} \boldsymbol{r}$. In the Steppe, Semidesert and Desert zones - very rare (see Table 4). Summarily, area occupied by the range of this species makes $98.6 \%$ of the total area of EEPEF.

Polytrichum piliferum. Distributed in all vegetation zones, except the Desert zone (see Fig. 3, Table 5). It does not reach status of widespread (com) in any region, but is a common species (fr $)$ in four regions (Fig. 3) for reasons that will be discussed below. About half of the area of EEPEF $(48.9 \%)$ is the zone of sporadic distribution $(\boldsymbol{s} \boldsymbol{p})$ of $P$. piliferum. In general, area of this species' range makes $97.0 \%$ of the total area studied (see Table 5).

Polytrichum byperboreum. This species occurs only in the Forest and the Tundra zones, though not everywhere

Table 2. Zones of abundance of $P$. commune by the vegetation zones, $\mathrm{km}^{2}$

\begin{tabular}{|c|c|c|c|c|c|c|c|c|}
\hline \multirow{2}{*}{ Zones } & \multicolumn{6}{|c|}{ Frequency } & \multirow{2}{*}{ Total } & \multirow{2}{*}{$\begin{array}{l}\text { Percent } \\
\text { of zones } \\
\text { from total }\end{array}$} \\
\hline & abs & vr & $\mathbf{r}$ & $\mathrm{sp}$ & fr & com & & \\
\hline Tundra & . & . & . & 45640.8 & 127773.4 & 18344.0 & 191758.2 & 3.9 \\
\hline Forest-Tundra & . & . & . & . & 32857.8 & 69234.1 & 102091.9 & 2.1 \\
\hline North Taiga & . & . & . & . & 13464.8 & 537262.9 & 550727.7 & 11.1 \\
\hline Middle Taiga & . & . & . & . & 26056.1 & 721963.5 & 748019.6 & 15.1 \\
\hline South Taiga & . & . & . & 27837.8 & 60211.7 & 451924.3 & 539973.8 & 10.9 \\
\hline Mixed Forest & . & . & . & 60038.7 & 53549.1 & 700736.5 & 814324.3 & 16.4 \\
\hline Broadleaves Forest & 6876.6 & 9558.3 & 96964.7 & 142404.7 & 176101.8 & 85244.3 & 517150.5 & 10.4 \\
\hline Forest-Steppe & 15938.7 & 120876.1 & 264708.6 & 108052.3 & 13127.1 & . & 522702.9 & 10.5 \\
\hline Steppe & 93930.3 & 516889.0 & 97763.5 & . & . & . & 708582.7 & 14.3 \\
\hline Semidesert & 112602.2 & 84781.5 & 7376.2 & . & . & . & 204760.0 & 4.1 \\
\hline Desert & 54859.7 & 4.1 & . & . & . & . & 54863.8 & 1.1 \\
\hline Total & 284207.5 & 732109.0 & 466813.0 & 383974.4 & 503141.8 & 2584709.6 & 4954955.4 & 100.0 \\
\hline $\begin{array}{l}\text { Percent of zones } \\
\text { from total }\end{array}$ & 5.7 & 14.8 & 9.4 & 7.7 & 10.2 & 52.2 & 100.0 & \\
\hline
\end{tabular}

Table 3. Zones of abundance of P. strictum by the vegetation zones, $\mathrm{km}^{2}$

\begin{tabular}{|c|c|c|c|c|c|c|c|c|}
\hline \multirow{2}{*}{ Zones } & \multicolumn{6}{|c|}{ Frequency } & \multirow{2}{*}{ Total } & \multirow{2}{*}{$\begin{array}{l}\text { Percent of } \\
\text { zones from } \\
\text { total }\end{array}$} \\
\hline & abs & vr & $\mathbf{r}$ & $\mathrm{sp}$ & fr & com & & \\
\hline Tundra & . & . & . & . & 16133.0 & 175625.2 & 191758.2 & 3.9 \\
\hline Forest-Tundra & . & . & . & . & 38746.2 & 63345.7 & 102091.9 & 2.1 \\
\hline North Taiga & . & . & . & . & 476885.4 & 73842.3 & 550727.7 & 11.1 \\
\hline Middle Taiga & . & . & . & . & 748019.4 & 0.2 & 748019.6 & 15.1 \\
\hline South Taiga & . & . & . & 2873.9 & 537099.9 & . & 539973.8 & 10.9 \\
\hline Mixed Forest & . & . & 23.8 & 48797.3 & 765503.2 & . & 814324.3 & 16.4 \\
\hline Broadleaves Forest & 9232.4 & 25763.8 & 81202.7 & 239879.1 & 161072.5 & . & 517150.5 & 10.4 \\
\hline Forest-Steppe & 95471.2 & 125261.1 & 209851.1 & 84758.6 & 7360.9 & . & 522702.9 & 10.5 \\
\hline Steppe & 566124.9 & 114985.9 & 27471.9 & . & . & . & 708582.7 & 14.3 \\
\hline Semidesert & 203871.1 & 888.9 & . & . & . & . & 204760.0 & 4.1 \\
\hline Desert & 54863.8 & . & . & . & . & . & 54863.8 & 1.1 \\
\hline Total & 929563.3 & 266899.7 & 318549.6 & 376308.9 & 2750820.5 & 312813.4 & 4954955.4 & 100.0 \\
\hline $\begin{array}{l}\text { Percent of zones } \\
\text { from total }\end{array}$ & 18.8 & 5.4 & 6.4 & 7.6 & 55.5 & 6.3 & 100.0 & \\
\hline
\end{tabular}




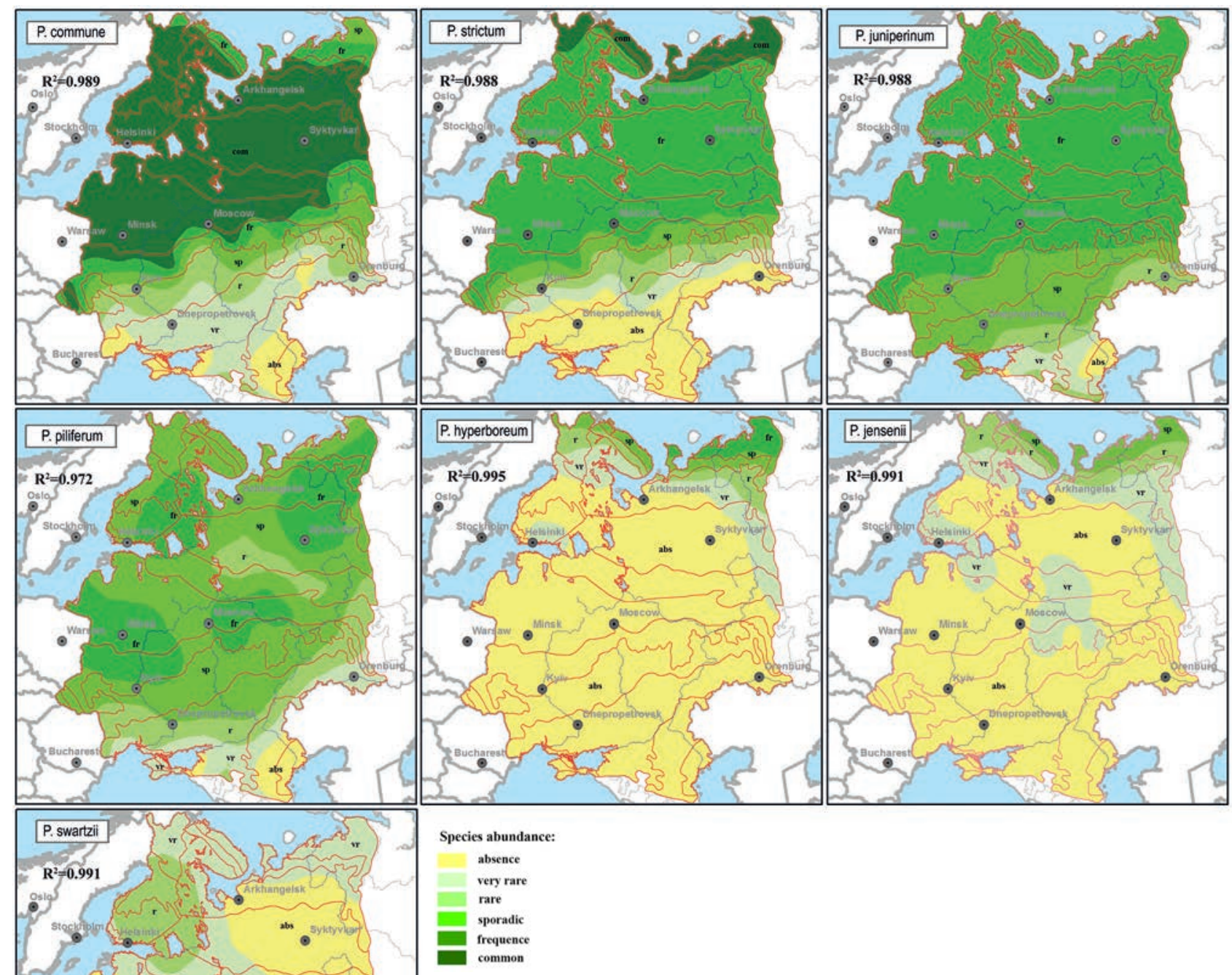

even in these regions (see Fig. 3, Table 6). It is not widespread anywhere, but in the Tundra it is characterized by frequent occurrence $(\boldsymbol{f} \boldsymbol{r})$. In general, this species' range occupies only $18.2 \%$ of the total area of EEPEF.

Polytrichum jensenii. This species is found in many vegetation zones, from the Forest-Steppe to the Tundra (see Fig. 3, Table 7), but reaches high occurrence nowhere. Sporadically occurs only in the northern part of its range, and the $\boldsymbol{s p}$ zone makes only $3.2 \%$ of its total area (see Table 7). Further to the south it becomes very rare. The $\boldsymbol{v r}$ zone makes the largest part of the range's area (19.2\%), and this sharply distinguishes this species' range from previous ones. In general, the P. jensenii area makes $27.3 \%$ of the total area of EEPEF.

Polytrichum swartzii. It is very unevenly distributed from the Forest-Steppe to the Tundra zones, being very rare in most places (see Fig. 3, Table 8). Within this species' range, one can distinguish the zones of very rare $(\boldsymbol{V} \boldsymbol{r})$ and rare $(\boldsymbol{r})$ occurrence. Area of zone $\boldsymbol{V} \boldsymbol{r}$ is about 3 times larger than that of the zone $\boldsymbol{r}$. The entire range of this species makes $31.6 \%$ of the total area of EEPEF.

Fig. 3 shows that four species: P. commune, P. strictum, $P$. piliferum and P. juniperinum, are spread widely throughout the territory of EEPEF and are quite abundant in most of the territory. Three other species: $P$. hyperboreum, P. jensenii and $P$. swartzii, occupy a smaller area, mainly in the northern regions, and have low occurrence. They are restricted species on the territory of EEPEF.

$P$. commune, P. strictum and P. juniperinum have the maximum occurrence in the Forest and the Tundra zones (see Fig. 3), which best correlates with the relative humidity indicators for August and September in the territory of EEPEF (Fig. 2). This is confirmed by a visual comparison of the corresponding maps (Fig. 2 and 3), and by the maximal po- 
Table 4. Zones of abundance of P. juniperinum by the vegetation zones, $\mathrm{km}^{2}$

\begin{tabular}{|c|c|c|c|c|c|c|c|}
\hline \multirow{2}{*}{ Zones } & \multicolumn{5}{|c|}{ Frequency } & \multirow{2}{*}{ Total } & \multirow{2}{*}{$\begin{array}{l}\text { Percent of } \\
\text { zones from } \\
\text { total }\end{array}$} \\
\hline & abs & $\mathrm{vr}$ & $r$ & sp & $\mathrm{fr}$ & & \\
\hline Tundra & . & . & . & . & 191758.2 & 191758.2 & 3.9 \\
\hline Forest-Tundra & . & 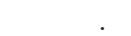 & . & . & 102091.9 & 102091.9 & 2.1 \\
\hline North Taiga & . & . & . & . & 550727.7 & 550727.7 & 11.1 \\
\hline Middle Taiga & . & . & . & . & 748019.6 & 748019.6 & 15.1 \\
\hline South Taiga & . & . & . & . & 539973.8 & 539973.8 & 10.9 \\
\hline Mixed Forest & . & . & & & 814324.3 & 814324.3 & 16.4 \\
\hline Broadleaves Forest & . & . & 3444.2 & 122087.2 & 391619.1 & 517150.5 & 10.4 \\
\hline Forest-Steppe & & & 5939.4 & 435747.1 & 81016.4 & 522702.9 & 10.5 \\
\hline Steppe & 2809.6 & 77382.7 & 200208.1 & 427502.8 & 679.5 & 708582.7 & 14.3 \\
\hline Semidesert & 22826.2 & 78760.7 & 59885.0 & 43288.1 & . & 204760.0 & 4.1 \\
\hline Desert & 41611.7 & 12432.1 & 820.0 & & & 54863.8 & 1.1 \\
\hline Total & 67247.5 & 168575.6 & 270296.7 & $1028625^{\circ} .2$ & 3420210.5 & 4954955.4 & 100.0 \\
\hline $\begin{array}{l}\text { Percent of zones } \\
\text { from total }\end{array}$ & 1.4 & 3.4 & 5.5 & 20.8 & 69.0 & 100.0 & \\
\hline
\end{tabular}

Table 5. Zones of abundance of P. piliferum by the vegetation zones, $\mathrm{km}^{2}$

\begin{tabular}{|c|c|c|c|c|c|c|c|}
\hline \multirow{2}{*}{ Zones } & \multicolumn{5}{|c|}{ Frequency } & \multirow{2}{*}{ Total } & \multirow{2}{*}{$\begin{array}{l}\text { Percent of } \\
\text { zones from } \\
\text { total }\end{array}$} \\
\hline & abs & vr & r & $\mathrm{sp}$ & fr & & \\
\hline Tundra & . & . & 11928.8 & 115124.8 & 64704.6 & 191758.2 & 3.9 \\
\hline Forest-Tundra & . & . & . & 62283.8 & 39808.1 & 102091.9 & 2.1 \\
\hline North Taiga & . & . & & 314498.9 & 236228.8 & 550727.7 & 11.1 \\
\hline Middle Taiga & $\dot{.}$ & . & 106806.2 & 381747.9 & 259465.5 & 748019.6 & 15.1 \\
\hline South Taiga & . & . & 84120.3 & 340075.0 & 115778.5 & 539973.8 & 10.9 \\
\hline Mixed Forest & $\dot{.}$ & $\dot{.}$ & 43686.8 & 389794.9 & 380842.6 & 814324.3 & 16.4 \\
\hline Broadleaves Forest & . & 15418.4 & 38501.5 & 237666.7 & 225563.8 & 517150.5 & 10.4 \\
\hline Forest-Steppe & . & 7707.9 & 103432.6 & 396646.4 & 14916.1 & 522702.9 & 10.5 \\
\hline Steppe & 14071.1 & 224015.1 & 283466.3 & 187030.2 & . & 708582.7 & 14.3 \\
\hline Semidesert & 78928.4 & 85850.5 & 39981.1 & 10700. & . & 204760.0 & 4.1 \\
\hline Desert & 54863.8 & & & & & 54863.8 & 1.1 \\
\hline Total & 147863.3 & 332991.8 & 711923.6 & 2424868.6 & 1337308.1 & 4954955.4 & 100.0 \\
\hline $\begin{array}{l}\text { Percent of zones } \\
\text { from total }\end{array}$ & 3.0 & 6.7 & 14.4 & 48.9 & 27.0 & 100.0 & \\
\hline
\end{tabular}

Table 6. Zones of abundance of $P$. hyperboreum by the vegetation zones, $\mathrm{km}^{2}$

\begin{tabular}{|c|c|c|c|c|c|c|c|}
\hline \multirow{2}{*}{ Zones } & \multicolumn{5}{|c|}{ Frequency } & \multirow{2}{*}{ Total } & \multirow{2}{*}{$\begin{array}{l}\text { Percent of } \\
\text { zones from } \\
\text { total }\end{array}$} \\
\hline & abs & vr & $\mathbf{r}$ & $\mathrm{sp}$ & fr & & \\
\hline Tundra & . & & 11727.1 & 62189.1 & 117842.0 & 191758.2 & 3.9 \\
\hline Forest-Tundra & & 2820.2 & 41805.1 & 55769.9 & 1696.8 & 102091.9 & 2.1 \\
\hline North Taiga & 150580.2 & 221641.8 & 151531.3 & 26974.4 & . & 550727.7 & 11.1 \\
\hline Middle Taiga & 632908.6 & 114426.3 & 684.7 & . & . & 748019.6 & 15.1 \\
\hline South Taiga & 453163.5 & 86810.3 & . & . & . & 539973.8 & 10.9 \\
\hline Mixed Forest & 806760.3 & 7564.0 & . & . & . & 814324.3 & 16.4 \\
\hline Broadleaves Forest & 517150.5 & . & $\dot{.}$ & . & . & 517150.5 & 10.4 \\
\hline Forest-Steppe & 522702.9 & . & . & . & . & 522702.9 & 10.5 \\
\hline Steppe & 708582.7 & . & . & . & . & 708582.7 & 14.3 \\
\hline Semidesert & 204760.0 & . & . & . & . & 204760.0 & 4.1 \\
\hline Desert & 54863.8 & & & & 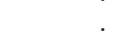 & 54863.8 & 1.1 \\
\hline Total & 4051472.5 & 433262.6 & 205748.2 & 144933.4 & 119538.8 & 4954955.4 & 100.0 \\
\hline $\begin{array}{l}\text { Percent of zones } \\
\text { from total }\end{array}$ & 81.8 & 8.7 & 4.2 & 2.9 & 2.4 & 100.0 & \\
\hline
\end{tabular}

sitive correlation coefficient between these indicators and the species' occurrence (see Table 9). At the same time, the ranges of these three species have some differences.

P. commune has the highest occurrence (valued 5 by our scale) in the Forest zone. Here it is found in the maximal number of biotopes, and is quite a common and widespread species. Fig. 3 shows that the boundaries of the com zone of this species coincide with the northern and southern boundaries of the Forest zone. Further to the south, it becomes rarer, but does not disappear from the cover completely. Its habitats here are associated with small individual bogs and humidoherbaceous habitats of the Steppe and the
Forest-Steppe zones. It is completely absent only in the Pontic and the Caspian lowlands, where higher temperatures are combined with low humidity and low precipitation (see Fig. 2; Alisov 1956). In addition to air humidity, P. commune is also quite sensitive to the amount of precipitation during the autumn-summer period (see Table 9) in the Forest zone. However, in the Tundra zone summer falls mainly on July. At this time, the amount of precipitation here is quite small. This is why this species' occurrence apparently falls to the north of the Forest zone, where summer precipitation also decreases (see Fig. 2). Still, the abundance of P. commune does not decrease there so sharply as to the south of the 
Table 7. Zones of abundance of $P$. jensenii by the vegetation zones, $\mathrm{km}^{2}$

\begin{tabular}{|c|c|c|c|c|c|c|}
\hline \multirow{2}{*}{ Zones } & \multicolumn{4}{|c|}{ Frequency } & \multirow{2}{*}{ Total } & \multirow{2}{*}{$\begin{array}{c}\text { Percent of } \\
\text { zones from total }\end{array}$} \\
\hline & abs & $\mathrm{vr}$ & $\mathbf{r}$ & $\mathrm{sp}$ & & \\
\hline Tundra & & 14011.8 & 43154.7 & 134591.7 & 191758.2 & 3.9 \\
\hline Forest-Tundra & & 10534.9 & 69903.5 & 21653.5 & 102091.9 & 2.1 \\
\hline North Taiga & 119735.2 & 295435.7 & 133136.8 & 2420.0 & 550727.7 & 11.1 \\
\hline Middle Taiga & 594413.4 & 153478.9 & 127.3 & . & 748019.6 & 15.1 \\
\hline South Taiga & 290791.8 & 249182.0 & . & . & 539973.8 & 10.9 \\
\hline Mixed Forest & 684535.7 & 129788.6 & 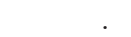 & . & 814324.3 & 16.4 \\
\hline Broadleaves Forest & 440345.8 & 76804.7 & . & . & 517150.5 & 10.4 \\
\hline Forest-Steppe & 502243.5 & 20459.4 & & . & 522702.9 & 10.5 \\
\hline Steppe & 708582.7 & . & . & . & 708582.7 & 14.3 \\
\hline Semidesert & 204760.0 & . & e & . & 204760 & 4.1 \\
\hline Desert & 54863.8 & & & & 54863.8 & 1.1 \\
\hline Total & 3600271.8 & 949696.1 & 246322.3 & 158665.2 & 4954955.4 & 100.0 \\
\hline $\begin{array}{l}\text { Percent of zones } \\
\text { from total }\end{array}$ & 72.7 & 19.2 & 5.0 & 3.2 & 100.0 & \\
\hline
\end{tabular}

Table 8. Zones of abundance of $P$. swartzii by the vegetation zones, $\mathrm{km}^{2}$

\begin{tabular}{|c|c|c|c|c|c|}
\hline \multirow{2}{*}{ Zones } & \multicolumn{3}{|c|}{ Frequency } & \multirow{2}{*}{ Total } & \multirow{2}{*}{$\begin{array}{l}\text { Percent of zones } \\
\text { from total }\end{array}$} \\
\hline & abs & vr & $\mathbf{r}$ & & \\
\hline Tundra & & 191758.2 & & 191758.2 & 3.9 \\
\hline Forest-Tundra & 7.5 & 102084.4 & & 102091.9 & 2.1 \\
\hline North Taiga & 219035.1 & 253968.1 & 77724.5 & 550727.7 & 11.1 \\
\hline Middle Taiga & 492559.6 & 101695.0 & 153765.0 & 748019.6 & 15.1 \\
\hline South Taiga & 221549.5 & 143775.5 & 174648.8 & 539973.8 & 10.9 \\
\hline Mixed Forest & 547383.0 & 265812.8 & 1128.5 & 814324.3 & 16.4 \\
\hline Broadleaves Forest & 425186.8 & 91963.7 & . & 517150.5 & 10.4 \\
\hline Forest-Steppe & 515776.6 & 6926.3 & . & 522702.9 & 10.5 \\
\hline Steppe & 708582.7 & . & . & 708582.7 & 14.3 \\
\hline Semidesert & 204760.0 & . & . & 204760.0 & 4.1 \\
\hline Desert & 54863.8 & & & 54863.8 & 1.1 \\
\hline Total & 3389704.5 & 1157984.1 & 407266.8 & 4954955.4 & 100.0 \\
\hline $\begin{array}{l}\text { Percent of zones } \\
\text { from total }\end{array}$ & 68.4 & 23.4 & 8.2 & 100.0 & \\
\hline
\end{tabular}

Forest zone, as in the Tundra high air humidity in the summer is retained due to low temperatures.

As for P. strictum, this species, on the contrary, increases its abundance to the north of the Forest zone. In the south its range disappears in the north of the Steppe zone, that is significantly further north than the range of P. commune. Table 9 shows that this species is more sensitive to air humidity than to the amount of precipitation. Apparently, this is due to the peculiarities of its ecology. Unlike P. commune, P. strictum is more stenotopic. In the Forest zone, it prefers oligotrophic boggy forests on peaty soils and bogs, and is lesser common on the sands. In the Tundra, where both peaty tundra soils and high air humidity are present, this species finds its optimal conditions for existence.

The occurrence of $P$. juniperinum does not exceed the grade frequent. It is rather monotonously distributed throughout the whole territory. Like P. strictum, it is quite stenotopic, but is found both on peat soils and on dry sands. Therefore, to the south of the Forest zone, where there are no boggy forests and only valley and karst bogs are present, it can grow on the forest litter in pine and birch picks. The air humidity here is lower than in the Forest zone, and this reduces the species' abundance. This species completely disappears from the cover only in the Desert zone - in the Caspian region (see Fig. 3).

A gradual decrease in the occurrence of the three described above species to the south of the Forest zone can be explained, in addition to changes in humidity, by higher summer temperatures - the species' occurrence has a high negative correlation coefficient with the monthly temperature averages of the vegetative season (see Table 9).

$P$. piliferum has an unique range pattern, which differs from those of other species. The maximum value of this species' occurrence on the territory of EEPEF is 4. It occurs with this frequency in four regions (see Fig. 3). Maximal distribution of this species correlates not with the climatic factors, but with distribution of the fluvioglacial deposits of the Last Glacial Maximum (Isachenko 1988), which fully conforms to the ecological preferences of this species: P. piliferum prefers to grow mainly on dry sands, where it is found in large quantities in lichen pine forests. However, in general occurrence of $P$. piliferum gradually diminishes to the south of the Forest zone, just like it is with other species (see Fig. 3). This fact is better explained by the change in climatic factors than by the landscape's peculiarities. High correlation coefficients of the species' occurrence and the precipitation and temperatures of the vegetative season make it evident (see Table 9). There is a zone of rare occurrence $(\boldsymbol{r})$ in the center of this species' range - in the Middle and the Southern Taiga (Vologda and Kirov Regions). Apparently, this is due to the lack of suitable habitats on sandy soils. Moraine ridges of the Valdai and the Moscow glaciations coincide in this region (Isachenko 1988), and they are composed of fairly rich morainic loams. 
Table 9. The Spearmen correlation coefficient between the values of climatic factors and species abundance and number of species (number_sp). Bold highlighted values of $\mathrm{r}>0.5$ in absolute value. All values are statistically significant at $p<0.05$

\begin{tabular}{|c|c|c|c|c|c|c|c|c|}
\hline \multirow{2}{*}{$\begin{array}{l}\text { Climatic } \\
\text { factor }\end{array}$} & \multicolumn{8}{|c|}{ Species name } \\
\hline & P. commune & P. strictum & P.juniperinum & P. piliferum & P. byperboreum & P.jensenii & P. swartzii & $\begin{array}{c}\text { Number of } \\
\text { species }\end{array}$ \\
\hline $\begin{array}{l}\text { pr01 } \\
\text { pr02 }\end{array}$ & $\begin{array}{l}-0.01 \\
-0.13\end{array}$ & $\begin{array}{l}-0.17 \\
-0.32\end{array}$ & $\begin{array}{l}-0.07 \\
-0.20\end{array}$ & $\begin{array}{l}0.02 \\
0.05\end{array}$ & $\begin{array}{l}-0.20 \\
-0.28\end{array}$ & $\begin{array}{l}-0.21 \\
-0.29\end{array}$ & $\begin{array}{l}-0.17 \\
-0.23\end{array}$ & $\begin{array}{l}-0.15 \\
-0.27\end{array}$ \\
\hline pr03 & 0.23 & -0.02 & 0.07 & 0.26 & -0.29 & -0.33 & 0.02 & -0.08 \\
\hline pr04 & 0.17 & -0.06 & 0.10 & 0.19 & -0.34 & -0.34 & -0.21 & -0.16 \\
\hline pr05 & 0.27 & 0.06 & 0.19 & 0.22 & -0.31 & -0.25 & -0.20 & -0.08 \\
\hline pr06 & 0.31 & 0.11 & 0.27 & 0.25 & -0.29 & -0.23 & -0.12 & -0.02 \\
\hline pr07 & 0.56 & 0.37 & 0.51 & 0.47 & -0.15 & -0.03 & 0.16 & 0.29 \\
\hline pr08 & 0.78 & 0.62 & 0.69 & 0.59 & 0.10 & 0.11 & 0.56 & 0.58 \\
\hline pr09 & 0.80 & 0.71 & 0.76 & 0.57 & 0.20 & 0.25 & 0.57 & 0.65 \\
\hline pr10 & 0.75 & 0.64 & 0.71 & 0.45 & 0.10 & 0.20 & 0.50 & 0.55 \\
\hline pr11 & 0.56 & 0.31 & 0.44 & 0.43 & -0.16 & -0.11 & 0.31 & 0.25 \\
\hline pr12 & 0.19 & -0.07 & 0.03 & 0.16 & -0.29 & -0.25 & -0.03 & -0.11 \\
\hline pr_a & 0.58 & 0.35 & 0.49 & 0.45 & -0.12 & -0.08 & 0.17 & 0.27 \\
\hline reh04 & 0.64 & 0.75 & 0.63 & 0.55 & 0.41 & 0.40 & 0.67 & 0.71 \\
\hline reh05 & 0.58 & 0.61 & 0.57 & 0.44 & 0.34 & 0.29 & 0.58 & 0.52 \\
\hline reh06 & 0.51 & 0.60 & 0.52 & 0.46 & 0.17 & 0.17 & 0.53 & 0.55 \\
\hline reh07 & 0.67 & 0.71 & 0.65 & 0.53 & 0.16 & 0.19 & 0.54 & 0.56 \\
\hline reh08 & 0.73 & 0.83 & 0.71 & 0.53 & 0.40 & 0.41 & 0.70 & 0.75 \\
\hline reh09 & 0.75 & 0.84 & 0.72 & 0.56 & 0.41 & 0.43 & 0.73 & 0.78 \\
\hline reh10 & 0.77 & 0.83 & 0.74 & 0.57 & 0.39 & 0.44 & 0.64 & 0.76 \\
\hline amt & -0.59 & -0.75 & -0.66 & -0.38 & -0.50 & -0.51 & -0.57 & -0.75 \\
\hline $\operatorname{tm} 01$ & -0.41 & -0.55 & -0.50 & -0.23 & -0.40 & -0.41 & -0.33 & -0.55 \\
\hline $\mathrm{tm} 02$ & -0.38 & -0.54 & -0.47 & -0.22 & -0.45 & -0.43 & -0.35 & -0.56 \\
\hline $\operatorname{tm} 03$ & -0.44 & -0.61 & -0.52 & -0.27 & -0.50 & -0.48 & -0.48 & -0.66 \\
\hline $\mathrm{tm} 04$ & -0.67 & -0.82 & -0.71 & -0.45 & -0.51 & -0.51 & -0.47 & -0.81 \\
\hline $\operatorname{tm} 05$ & -0.72 & -0.86 & -0.75 & -0.50 & -0.51 & -0.50 & -0.43 & -0.82 \\
\hline $\operatorname{tm} 06$ & -0.73 & -0.86 & -0.75 & -0.53 & -0.59 & -0.58 & -0.49 & -0.82 \\
\hline $\mathrm{tm} 07$ & -0.74 & -0.85 & -0.73 & -0.56 & -0.67 & -0.65 & -0.54 & -0.82 \\
\hline $\operatorname{tm} 08$ & -0.72 & -0.86 & -0.75 & -0.50 & -0.51 & -0.59 & -0.58 & -0.83 \\
\hline $\operatorname{tm} 09$ & -0.70 & -0.84 & -0.74 & -0.48 & -0.50 & -0.51 & -0.54 & -0.82 \\
\hline $\mathrm{tm} 10$ & -0.55 & -0.71 & -0.62 & -0.35 & -0.49 & -0.50 & -0.51 & -0.72 \\
\hline $\mathrm{tm} 11$ & -0.48 & -0.64 & -0.57 & -0.29 & -0.46 & -0.47 & -0.42 & -0.65 \\
\hline $\mathrm{tm} 12$ & -0.44 & -0.59 & -0.53 & -0.26 & -0.43 & -0.44 & -0.37 & -0.60 \\
\hline pr_clq & 0.04 & -0.15 & -0.05 & 0.11 & -0.17 & -0.17 & -0.16 & -0.10 \\
\hline pr_drm & 0.14 & -0.05 & 0.02 & 0.26 & -0.12 & -0.17 & -0.08 & -0.01 \\
\hline pr_drq & 0.11 & -0.10 & 0.02 & 0.20 & -0.19 & -0.22 & -0.15 & -0.09 \\
\hline pr_wmq & 0.58 & 0.37 & 0.52 & 0.47 & -0.12 & -0.08 & 0.16 & 0.28 \\
\hline pr_wtm & 0.55 & 0.36 & 0.49 & 0.48 & -0.13 & -0.05 & 0.22 & 0.30 \\
\hline pr_wtq & 0.60 & 0.40 & 0.53 & 0.49 & -0.09 & -0.06 & 0.22 & 0.31 \\
\hline t_clq & -0.39 & -0.54 & -0.48 & -0.22 & -0.41 & -0.41 & -0.32 & -0.54 \\
\hline t_drq & -0.55 & -0.66 & -0.61 & -0.37 & -0.35 & -0.41 & -0.50 & -0.63 \\
\hline t_wmq & -0.73 & -0.86 & -0.75 & -0.52 & -0.49 & -0.47 & -0.70 & -0.82 \\
\hline t_wtq & -0.66 & -0.78 & -0.66 & -0.45 & -0.45 & -0.41 & -0.66 & -0.74 \\
\hline
\end{tabular}

Unlike all other species, P. juniperinum and P. piliferum penetrate furthest to the south. However, P. juniperinum occupies larger areas in the Desert and Semi-Desert zones in the Caspian region. Apparently, this is due to a broader coenotic amplitude of $P$. juniperinum, as compared to P. piliferum: the latter grows mainly on sands, while $P$. juniperinum is able to grow on clay substrates.

P. byperboreum and P. jensenii prevail mainly in the north of EEPEF. To the south, they are distributed only along the Tundras of the Ural Mountains (see Fig. 3). The pattern of their range shows that these species are hypoarctic ones. Among the climatic factors, the annual and monthly temperature averages have a significant effect on their distribution (see Table 9). P. swartzii also has rather low occurrence in its distribution areas (see Fig. 3). However, it can not be called hypoarctic, since its distribution maximum is located to the south of the Taiga zone (in Finland and Karelia), and is limited to the region with maximal precipitation and humidity (Fig. 2, Table 9). Although this species is distributed mostly throughout the tundra zone, its range stretches like a tongue-shaped band to the center of European Russia (see
Fig. 3). In my opinion, this may be due to anthropogenic factors, since this species prefers disturbed habitats (e.g. burns, cuttings, pits, etc.), at least in the south of the Forest zone. In any case, the ranges of these three species look reducing, because 1) they occupy rather a small part of EEPEF, and 2) total area of zones of their rare occurrence is notably larger than that of the zones of higher occurrence.

If we continue to study distribution of the species' ranges of the genus Polytrichum to the west of the study area, we can see that $P$. hyperboreum, $P$. jensenii and $P$. swartzii are common in the mountains of Sweden and Norway, in Svalbard and in Greenland (Söderström 1998, Goldberg 2003). These three species are absent in the continental part of Western Europe and in Great Britain. So, in Europe the borders of their ranges project most far southwards on the territory of EEPEF. Four species: P. commune, P. juniperinum, P. piliferum and P. strictum, are widespread throughout Europe, including Southern and Western Europe, Scandinavia, Svalbard, and Great Britain (Casas 1991, Hill et al. 2006, Sabovljević et al. al. 2008, Atherton et al. 2010). In Southern Europe, P. juniperinum is found most frequently, and P. stric- 
tum is quite rare. But the latter, unlike P. juniperinum, increases its occurrence in Scandinavia, Svalbard and Greenland. $P$. commune and P. piliferum are more or less evenly distributed throughout Western Europe, still P. piliferum may be absent in some places - for example, in the Alps, where there are no sandy soils (Privitera et al. 2010). P. piliferum also goes much further into Southern Europe than P. commune. All these facts are fully consistent with the patterns of species' distribution that we have established for the territory of EEPEF. In Siberia, P. commune, P. strictum, P. juniperinum and $P$. piliferum occur throughout all the territory, and their occurence patterns seem to be similar with those for EEPEF. $P$. hyperboreum and P. jensenii pass through the North of Siberia and go down further to the south in the Far East. $P$. swartzii grows in the Northern Siberia, and occurs in some localities in Southern Siberia (Ignatov 2017).

As it is seen from Tables 2-8, the species with high occurrence (P. commune, $P$. strictum, $P$. juniperinum, $P$. piliferum) are also widely spread. For these species, the area of high occurrence zones is several times larger than that of the low occurrence zone. The boundaries of their ranges generally coincide with the boundaries of vegetation zones and the isotherms of July and August (see Fig. 2 and 3). Apparently, the temperature is a limiting factor for these species, and the decreasing occurrence of these species nearer to the southern and northern limits of their distribution range fully conforms to the rule of tolerance of Shelford (1931). The inverse ratio is observed for the rare species ( $P$. hyperboreum, $P$. jensenii, $P$. swartizi): the area of very low occurrence zones is several times larger than that of higher occurrence zones. Moreover, such species do not have a continuous distribution range on the territory of EEPEF. As it was already mentioned, their distribution is mainly limited by the Tundra zone.

Map of species' diversity taken on the basis of individual species distribution (Fig. 4), shows that on the north and north-east of studying area pattern of the species number

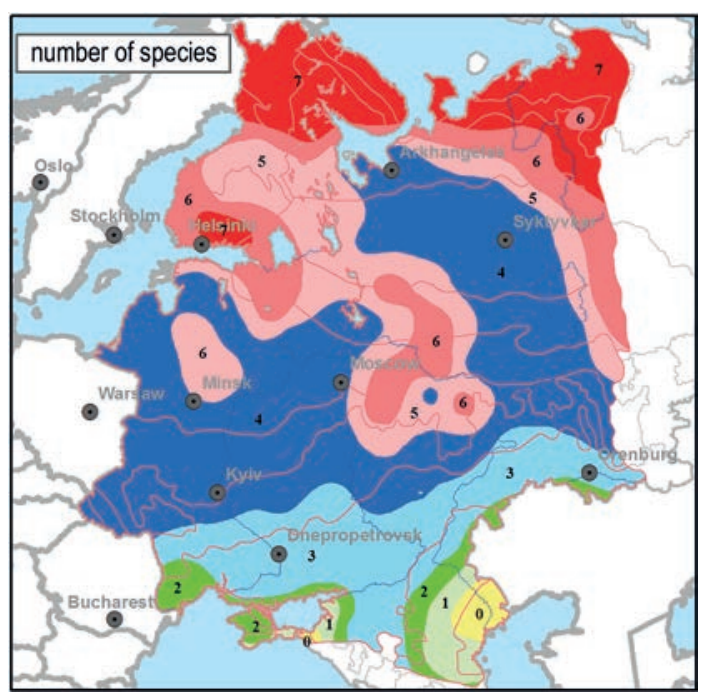

Figure 4 Map of species number distribution (areas with corresponding species numbers are given in color; numbers on the map are the number of species) decreasing is too similar to the spatial pattern of July-temperature decreasing (Fig. 4). In other parts of the EEPEF patterns of species diversity look uneven, that is most likely due to the combining effects of climatic, landsape and random factors. As correlation analysis shows distribution of species number through the territory depends in general mostly on temperatures and humidity than on precipitation (Table 9).

\section{CONCLUSION}

Seven species of the genus Polytrichum can be divided into two groups according to the pattern of their distribution on EEPEF: 1) widespread species (P. commune, P. strictum, P. juniperinum, P. piliferum) and 2) restricted species (P. byperboreum, P. jensenii, P. swartzi $i)$. Species of the first group find their climatic optimum mostly in the Forest zone, while species of the second group find it mostly in the Tundra zone. The distribution boundary of Polytrichum juniperinum extends most far to the south, as this species requires lesser moisture than others. Distribution range of P. piliferum is determined not only by climatic parameters, but also by distribution of fluvioglacial deposits on EEPEF. Distribution of widespread species from the first group follows the spread of forests in the southern part of EEPEF. Distribution of species of the second group is mainly limited to Subarctic regions and their ranges look reducing.

\section{LITERAT URE CITED}

Abakarova, A.S., V.E. Fedosov \& G.Ya. Doroshina 2015. Mosses of Tsudakhar (Dagestan, Caucasus). Arctoa 24: 536-540.

Abolin', A.A. 1968. Mosses of Latvian SSR. Zinatne, Riga, 329 pp. (in Russian). [Аболинь А.А. 1968. Аистостебельные мхи Аатвийской ССР. Рига: Зинатне. 329 с.].

Abramov, I.I. \& L.A. Volkova 1998. Handbook of mosses of Karelia. Arctoa 7, suppl. 1: 1-390 (in Russian). [Абрамов И.И., Волкова А.А. 1998. Определитель мистостебельных мхов Карелии // Arctoa. Vol. 7, suppl. 1. 390 с.].

Afonina, O.M. \& I.V. Chernyadyeva 1995. Mosses of the Russian Arctic: checklist and bibliography. Arctoa 5:99-142.

Ahti, T., L. Hämet-Ahti \& J. Jalas 1968. Vegetation zones and their sections in northwestern Europe. Annales Botanici Fennici 5:169-211.

Akatova, T.V. 2002. Moss flora of the Caucasian Nature Reserve (Western Caucasus, Russia). Arctoa 11:179-204 (in Russian with English summary). [Акатова T.B. 2002. Аистостебельные мхи Кавказского заповедника (Западный Кавказ, Россия) // Arctoa. Т. 11. С. 179-204].

Akatova, T.V. \& E.A. Ignatova 2015. On the moss flora of Lagonaki Highland (Adygea Rebublic, Western Caucasus). Arctoa 24:148-155.

Alisov, B.P. 1956. The climate of the USSR. Izdatel'stvo MGU, Moscow, 126 pp. (in Russian) [А^исов Б.П. 1956. КАимат СССР. М.: ИзА-во МГУ. 126 с.].

Andreeva, E.N. \& E.O. Filip'eva 2005. Bryophyta of the Remda Reservation (Pskov Region). Novosti sistematiki nizshih rastenii 38:307-327 (in Russian). [Андреева E.H., Филипьева Е.О. 2005. Мохообразные заказника "Ремдовский” (Псковская область) // Новости систематики низших растений. Т. 38. С. 307-327].

Ariskina, N.P. 1978. Mosses of Tatar ASSR: guide. Kaznskii universitet, Kazan, 122 pp. (in Russian). [Арискина Н.П. 
1978. Краткий определитель мистостебельных мхов Татарской АССР. Казань: Казанский университет. $122 \mathrm{c.}]$.

Arrehnius, O. 1921. Species and area. Journal of Ecology 9(1): 95-99.

Atherton, I., S. Bosanquet \& M. Lawley (eds) 2010. Mosses and liverworts if Britain and Ireland: a field guide. British Bryological Society, $850 \mathrm{pp}$.

Baisheva, E.Z., Ignatova E.A., Kalinauskaite N. \& A.D. Potemkin 2015. On the Bryophyte flora of Iremel National Park (Southern Urals). Arctoa 24(1):194-203.

Belkina, O.A. \& A.Yu. Likhachev 1997. Mosses of Kandalaksha State Nature Reserve (White Sea). Kola Science Center, Apatity, 46 pp. (in Russian). [Белкина O.A., Аихачев А.Ю. Конспект флоры мистостебельных мхов Кандалакшского заповедника (Белое море). Апатиты: Кольский научный центр РАН. 46 с.]

Belkina, O.A. \& A.Yu. Likhachev 2004. Moss flora of Chiltald and Ionn-Njugoayv Mountains (Murmansk Province, Russia). Arctoa 13:211-222 (in Russian with English summary). [Белкина О.А., Аихачев А.Ю. 2004. ФАора мистостебельных мхов горных массивов ЧильтальА и Ионн-Ньюгоайв (Мурманская область) // Arctoa. T. 13. C. 211-222].

Belkina, O.A. \& A.Yu. Likhachev 2010. The check-list of mosses of Lappland State Reserve. Vestnik MGTU 13(4/2):984-988 (in Russian with English summary). Белкина О.А., Аихачев А.Ю. 2010. Список Аистостебельных мхов Аапландского заповедника // Вестник МГТУ. Т. 13, № 4/2. С. 984-988].

Bezgodov, A.G. 2002. On the bryoflora of the Kungur city environs (Perm Province). Arctoa 11:53-62 (in Russian with English summary). [Безгодов А.Г. 2002. К бриофлоре окрестностей Кунгура (Пермская обмасть) // Arctoa. T. 11. С. 53-62].

BIOCLIM project. 2009. URL: http://www.andra.fr/bioclim (last check 23.03.2018).

Bogdanova, N.E. 1981. Bryophytes of Velikiy Island (White Sea). In: Florstic researches in the Nature Reserves of the USSR pp. 103-112, Moscow (in Russian). [Богданова H.E. 1981. Мохообразные острова Великий (Белое море) // ФАористические исследования в заповедниках CССР. M. C. 103-112].

Boichuk, M.A. 2001. On the moss flora of the Kostomuksha State Reserve and the vicinities of Kostomuksha town (Karelia). Novosti sistematiki nizshih rastenii 35:217-229 (in Russian). [Бойчук М.А. 2001. Кфморе листостебельных мхов заповеАника "Костомукшский” и окрестностей города Костомукша (Карелия) // Новости систематики низших растений. Т. 35. С. 217-229].

Boichuk, M.A. 2002. Mosses of protected areas of Karelia. Ph.D. Thesis. Petrozavodsk. 157 pp. (in Russian). [Бойчук M.A. 2002. Аистостебельные мхи особо охраняемых природных территорий Карелии. Аисс. канА. биол. наук. Петрозаводск. 157 с.].

Boichuk, M.A., V.K. Antipin, V.A. Bakalin \& P.N. Lapshin 2002. Contribution to the bryoflora of Vodlozero National Park. Novosti sistematiki nizshib rastenii 36:213-224 (in Russian). ББойчук М.А., Антипин В.К., Бакалин В.А., Аапшин П.Н. 2002. Материалы к изучению бриофлоры ВоАлозерского национального парка // Новости систематики низших растений. Т. 36. С. 213-224].

Boiko, M.F. 2009. Bryobiota of the Steppe zone of Ukraine. Ailant, Kherson, 264 pp. (in Ukrainian). [Бойко М.Ф. 2009. Мохоподібні степовоі зони Украіни. Херсон: Айлант. 264 с.].

Bolyukh, V.A. 1995. A comparison of moss flora of Central
Podolia (Ukraine) and adjacent regions. Arctoa 4:45-54 (in Russian with English summary). [Болюх B.A. 1995 Сравнение флоры мхов центральной части Подолии (Украина) и сопредельных регионов // Arctoa. Т. 4. C. 45-54].

Casas, C. 1991. New check-list of Spanish mosses. Orsus 6:3-26.

Churakova, E.Yu. 2002. Mosses of the Taiga zone of the Arkhangelsk Region (Northern European Russia). Arctoa 11:351-392 (in Russian with English summary). [Чуракова Е.Ю. 2002. Аистостебельные мхи таежной зоны Архангельской области // Arctoa. T. 11. С. 351-392].

Clymo, R.S., Hayward P.M. The ecology of Sphagnum. In: Bryophyte ecology (A.J.E. Smith, ed.), pp. 229-289. Chapman \& Hall, London.

Chernyadyeva, I.V. 1994. The moss flora of the region of Sob Station (Polar Ural). Arctoa 3:133-138 (in Russian with English summary). [Чернядьева И.В. 1994. ФАора мистостебельных мхов окрестностей стационара «Собь» // Arctoa. T. 3. С. 133-138].

Chernyadyeva, I.V. 2001a. Mosses of Bol'shaya Kokshaga State Reserve. Novosti sistematiki niashyh rastenii 35:266-278 (in Russian with English summary). [Чернядьева И.В. 2001. Аистостебельные мхи заповедника Большая Кокшага // Новости систематики низших растений. T. 35. C. 266-278].

Chernyadyeva, I.V. 2001b. Moss flora of Yamal Peninsula (West Siberian Arctic). Arctoa 10:121-150.

Chernyadyeva, I.V., N.A. Konstantinova, G.A. Bogdanov \& S.Yu. Popov 2013. The Anthocrotae and Bryophytic in the Bolshaya Kokshaga Reserve. Nauchnye trudy zapovednika Bolshaya Kokshaga 6:91-119 (in Russian with English summary). [Чернядьева И.В., Константинова Н.А., Богданов Г.А., Попов С.Ю. 2013. Антоцеротовые и мохообразные заповедника Большая Кокшага // Научные труды заповедника Большая Кокшага. № 6. C. 91-119].

Danilenko, A.K. \& V.Yu. Rumyantsev 2000. The role of animal habitats maps in mapping their biological diversity. Trudy Karel'skogo Nauchnogo Tsentra 8:31-35 (in Russian with English summary). [Ааниленко А.К., Румянцев В.Ю. 2000. Роль карт местообитаний животных при картографировании их биологического разнообразия // Труды КарНЦ. №8. С. 31-35].

Demyanov, V.V. \& E.A. Savelyeva 2010. Geostatistics: Theory and Practice. Nauka, Moscow. 327 pp. (in Russian). [Аемьянов В.В., Савельева Е.А. 2010. Геостатистика: теория и практика. М.: Наука. 327 с.].

Dite, D., Hajek M. \& P. Hajkova 2007. Formal definition of Slovackian mire plant associations and their application in regional research. Biologia 62(4):400-408.

Dyachenko, A.P., Ignatova E.A. \& L.V. Marina 1996. Mosses of the Visimskij State Reserve (Middle Ural Mountains). Arctoa 6:1-6 (in Russian with English summary). [Аьяченко А.П., Игнатова Е.А., Марина А.В. 1996. Мхи Висимского заповедника (Средний Урал) // Arctoa. T. 6. C. 1-6].

Dyachenko, A.P. \& E.A. Dyachenko 2010. Mosses of the reserve «Denezhkin Kamen'». In: Bryology: Tradition and modernity, pp. 59-64. Attache, S.-Peterburg (in Russian). [Аьяченко А.П., Аьяченко Е.А. Мхи заповеАника Аенежкин камень // Бриология: традиции и современность. Сборник статей по материалам межАународной бриомогической конференции, посвященной 110-летию со Аня рождения 3.Н. Смирновой и К.И. Аадыженской. СПб.: ИзА-во ЗАО “Атташе”. 2010. С. 59-64].

Dolnik, C. \& M.G. Napreenko 2007. The bryophytes of 
the Southern Curonian Spit (Baltic Sea coast). Arctoa 16:35-46.

Doroshina-Ukrainskaya, G.Ya. 1999. Bryophytes. In: Proceedings of the state nature reserve "Privolzhskaya forest-steppe", pp. 43-46. Penza (in Russian). [Аорошина-Украинская Г.Я. 1999. Мохообразные / / Труды государственного заповедника “Приволжская месостепь". Пенза. С. 43-46].

Doroshina, G.Ya. 2011. Mosses of the Southern Kalmykia (European part of Russia). Novosti sistematiki nizshib rastenii 45:292-300 (in Russian with English summary). [Aoрошина Г.Я. 2011. Мхи Южной Калмыкии (Европейская часть России) // Новости систематики низших растений. Т. 45. С. 292-300].

Doroshina, G.Ya. 2015. The mosses (Bryophyta) of Abkhazia. Novosti sistematiki nizshib rastenii 49:295-313 (in Russian with English summary). [Аорошина Г.Я. 2015. Мхи (Bryophyta) Абхазии // Новости систематики низших растений. Т. 49. С. 295-313].

Drugova, T.P., O.A. Belkina \& A.Yu. Likhachev 2017. Mosses of surroundings of Alakurttii settlement and Kutsa nature reserve (Murmansk Province, North-West Russia). Arctoa 26(1):72-80.

Erzberger, P., Hohn M. \& T. Pocks 2012. Contribution to the bryoflora of Câlimani Mountains in the Eastern Carpatians, Romania. Acta Biologica Plantarum Agriensis 2:73-95.

Fedosov, V.E. \& S.Yu. Popov 2004. Bryophyte flora of Kostromskaya Taiga Station (European Russia, Kostroma Province). Arctoa 13:183-195 (in Russian with English summary). [Федосов В.Э., Попов С.Ю. 2004. Бриофлора Костромской таежной станции // Arctoa. T. 13. C. 183-195].

Filippov, D.A. \& M.A. Boichuk 2015. The mosses of Shichengsky Reserve (Vologda Province). Vestnik severnogo (Arkticheskogo) federal'nogo universiteta. Seria: Estestvennye nauki 2:80-89 (in Russian). [Филиппов А.А., Бойчук M.A. 2015. Мхи Шиченгского заказника (Вологодская обмасть) // Вестник Северного (Арктического) федерального университета. Серия: Естественные науки. Вып. 2. C. 80-89].

Gapon, S.V. 1997. Check-list of bryoflora of Ukrainian Leftbank Forest-Steppe. Poltava. 37 pp. (in Ukrainian). [Гапон C.B. 1997. Конспект бріофмори мівобережного місостепу Украіни. Полтава: Полтавський державний педагогічний інститут им. В.Г. Короленка. 37 с.].

GBIF. Global Biodiversity Information Facility. https:// www.gbif.org/. Last check 05.05.2018.

Geffert, J.L., J.-P. Frahm, W. Barthlott \& J. Mutke 2013. Global moss diversity: spatial and taxonomic patterns of species richness. Journal of Bryology 35(1):1-11.

Gignac, L.D. \& D.V. Vitt 1990. Habitat limitation of Sphagnum along climatic, chemical and physical gradients in mires of Western Canada. The Bryologist 93(1):7-22.

Gignac, D., D.H. Vitt, S.C. Zoltai \& S.E. Bayley 1991. Bryophyte response surface along climatic, chemical and physical gradients in peatlands of Western Canada. Nova Hedwigia 53(1-2):27-71.

Goldberg, I. 2003. Mosses of Greenland: List of species in the Herbarium C. Unpublished manuscript, Copenhagen, mobot.org. Last check 05.05.2018.

Grinnel, J. 1917. The niche-relationships of the California Thrasher. The Auk 34:427-433.

Hájková P. \& M. Hájek 2007. Sphagnum distribution patterns along environmental gradients in Bulgaria. Journal of Bryology 9:18-26.

Hijmans, R.J., S.E. Cameron, J.L. Parra, P.G. Jones \& A. Jar- vis 2005. Very high resolution interpolated climate surfaces for global land areas. International Journal of Climatology 25:1965-1978.

Hill, M.O., N. Bell, M.A. Bruggemann-Nannenga, M. Brugues, M.J. Cano, J. Enroth, K.I. Flatberg, et al. 2006. An annotated checklist of the mosses of Europe and Macaronesia. Journal of Bryology 28(3):198-267.

Hutchinson, G.E. 1965. The ecological theater and the evolutionary play. Yale University Press, New Haven, 139 pp.

Ignatov, M.S. 1993. Moss diversity patterns on the territory of the former USSR. Arctoa 2:13-47.

Ignatov, M.S. (ed.) 2017. Moss flora of Russia, vol. 2. Oedipodiales-Grimmiales. KMK Scientific Press Ltd., Moscow. 560 pp. (in Russian). [ФАора мхов России. T. 2. Oedipodiales-Grimmiales. 2017. Отв.реА. M.С. Игнатов. М.: КМК. 560 c.].

Ignatov, M.S., V.E. Fedosov \& E.A. Ignatova 2010. Moss flora of Gunib Area in Dagestan, Eastern Caucasus. Arctoa 19:87-96.

Ignatov, M.S. \& E.A. Ignatova 1994. Contribution for the knowledge of brioflora in the Moscow Region. In: Floristic researhes in Moscow Region, pp. 121-179, Nauka, Moscow (in Russian). [Игнатов M.С., Игнатова Е.А. 1994. Материалы к познанию бриофлоры Московской области // ФАористические исследования в Московской обмасти. М.: Наука. С. 121-179].

Ignatov, M.S., Ignatova E.A. 2003. Moss flora of Middle European Russia. Arctoa 11, suppl. I:1-608. [Игнатов M.С., Игнатова Е.А. 2003. ФАора мхов средней части Европейской России. Т.1. М.: КМК, 608 с.]

Ignatov, M.S., E.A. Ignatova, V.E. Fedosov \& N.A. Konstantinova 2011. Bryophytes of Moscow Province: a gude. KMK Scientific Press Ltd., Moscow. 320 pp. (in Russian). [Игнатов М.С., Игнатова Е.А., Федосов В.Э., Константинова Н.А. 2011. Краткий определитель мохообразных Подмосковья. М.: КМК. 320 с.].

Ignatov, M.S., E.A. Ignatova \& N.A. Konstantinova 2005. Bryophyte flora of the Volzhsko-Kamskiy Nature Reserve (Tatarstan, European Russia). Arctoa 14:49-66.

Ignatov, M.S., E.A. Ignatova, E.N. Kuraeva, T.Yu. Minaeva \& A.D. Potemkin 1998. Bryophyte flora of Zentral'noLesnoj Biosphere Nature Reserve (European Russia, Tver Province). Arctoa 7:45-58.

Ignatov, M.S., E.A. Ignatova, S.Yu. Popov, E.Yu. Churakova, T.Yu. Braslavskaya \& I.B. Kucherov 2008. Mosses. In: Ecosystem components and biodiversity of karst areas of Russian European North-East, pp. 177-197, GPZ «Pinezhsky», Arkhangelsk (in Russian). [Игнатов M.С., Игнатова Е.A., Попов С.Ю., Чуракова Е.Ю., Браславская Т.Ю., Кучеров И.Б. 2008. Аистостебельные мхи // Компоненты экосистем и биоразнообразие карстовых территорий Европейского Севера России. Архангельск: ГПЗ "Пинежский”. С. 177-197].

Ignatova, E.A., M.S. Ignatov \& A.G. Bezgodov 1995. Moss flora of the Basegi State Reserve (Perm Province, Middle Ural Mountains). Arctoa 4:23-34.

Ignatova, E.A., M.S. Ignatov \& A.G. Bezgodov 1996. Mosses of the Vishera State Reserve (Perm Province, Northern Ural Mountains). Arctoa 6:7-19 (in Russian with English summary). [Игнатова Е.А., Игнатов M.С., Безгодов А.Г. 1996. Мхи Вишерского заповедника (Пермская область, Северный Урал) // Arctoa. Т. 6. С. 7-19].

Ignatova, E.A., M.S. Ignatov, N.A. Konstantinova, V.I. Zolotov \& V.G. Onipchenko 2008. Moss flora of Teberda Reserve. Moscow. 86 pp. (in Russian). [Игнатова E.A., Игнатов М.С., Константинова Н.А., Золотов В.И., Онипченко В.Г. 2008. ФАора мохообразных Тебер- 
Аинского заповедника. М. 86 с.].

Ignatova, E.A., M.S. Ignatov, A.P. Seregin, T.V. Akatova \& N.A. Konstantinova 2005. Bryophyte flora of the projected Utrish Reserve (North-West Caucasus, Russia). Arctoa 14:39-48.

Isachenko, A.G. (ed.) 1988. Map of landscapes of the USSR. Moscow (in Russian). [Аандшафтная карта СССР / поА ред. А.Г. Исаченко. 1988. Москва].

Ivanov, O.V., M.A. Kolesnikova, O.M. Afonina, T.V. Akatova, E.Z. Baisheva, O.A. Belkina, A.G. Bezgodov et al. 2017. The database of the moss flora of Russia. Arctod 26(1):1-10.

Karmazina, E.V. 2013. Ecologo-coenotic characteristics of bryophytes in the "Russian North» National Park. PhD Thesis. Moscow. 244 pp. (in Russian). [Кармазина E.B. 2013 Эколого-ценотическая характеристика мохообразных национального парка «Русский Север». Аисс. канА. биол. наук. М. 244 с.].

Kharzinov, Z., N. Portenier, E. Ignatova, S. Shagapsoev \& M. Ignatov 2004. Rare species and preliminary list of mosses of the Kabardino-Balkaria (Caucasus). Arctoa $13: 33-40$

Kier, G., J. Mutke, E. Dinerstein, T.H. Ricketts, W. Kuper, H. Kreft \& W. Barthlott 2005. Global patterns of plant diversity and floristic knowledge. Journal of Biogeigraphy 32:1107-1116.

Krestov, P.V., J.-S. Song, Y. Nakamura \& V.P. Verkholat 2006. A phytosociological survey of the deciduous temperate forests of mainland Northeast Asia. Phytocoenologia 36(1):77-150.

Kurbatova, L.V. 2002. Mosses of the Leningrad Province. Ph.D. Thesis. S.-Peterburg. 211 pp. (in Russian). [Курбатова А.В. 2002. Аистостебельные мхи Аенинградской области. Аисс. канА. биол.наук. С-Пб. 211 с.].

Kurnaev, S.F. 1973. Forest zoning in the USSR, Nauka, Moscow, 203 pp. (in Russian). [Курнаев С.Ф. 1973. Аесорастительное районирование СССР. М.: Наука. 203 с.].

Lahti, T. \& R. Lampinen 1999. From dot maps to bitmaps: Atlas Florae Europeae goes digital. Acta Botanica Fennica 162:5-9.

Lazarenko, A.S. 1955. Handbook of mosses of Ukraine. AN Ukrainy, Kiev, 467 pp. (in Russian). [Аазаренко A.C. 1955. Определитель мистостебельных мхов Украины. Киев: ИзА-во АН Украины. 467 с.].

Likhachev, A.Yu. \& O.A. Belkina 1999. Mosses of LavnaTundra Mountains (Murmansk Province, Russia). Arctoa 8:5-16 (in Russian with English summary). [Аихачев А.Ю., Белкина О.А. 1999. Аистостебельные мхи горного массива $\Lambda$ авна-тундра (Мурманская область, Россия) // Arctoa. T. 8. С. 5-16].

Lurye, I.K. 2010. Geoinformatical mapping. The methods of geoinformatics and digital processing of satellite images. KDU, Moscow, 424 pp. (in Russian). [Аурье И.К. 2010. Геоинформационное картографирование. Методы геоинформатики и цифровой обработки космических снимков. М.: КАУ. 424 с.].

Maksimov, A.I. 1982. Ecology of several peat mosses in Karelia and their role in plant communities. In: Ekologobiologicheskie osobennosti i produktivnost' rastenii bolot, pp. 187 195. Petrozavodsk (in Russian). [Максимов А.И. 1982. Фитоценотическое значение и экология некоторых сфагновых мхов Карелии // Эколого-биологические особенности и продуктивность растений болот. Петрозаводск. С. 187-195].

Maksimov, A.I., O.L. Kuznetsov \& T.A. Maksimova 2009. Moss flora of the planned national park Tulos (Republic of Karelia). Novosti sistematiki nizshih rastenii 36:362-376 (in Russian with English summary). [Максимов А.И., Кузнецов О.А., Максимова Т.А. 2009. ФАора мхов планируемого национального парка "Тулос" (Республика Карелия) // Новости систематики низших растений. Т. 43. С. 362-376].

Mateo, R.G., A. Felicisimo \& J. Muñoz 2011. Species distributions models: A synthetic revision. Revista Chilena de Historia Natural 84:217-240.

Mateo, R.G., A. Vanderpoorten, J. Muñoz, B. Laenen \& A. Désamoré 2013. Modeling species distributions from heterogeneous data for the biogeographic regionalization of the European Bryophyte Flora. PLOS ONE 8(2): e55648.

Melosik, I. 2006. Species of the type section of Sphagnum (Bryophyta, Sphagnaceae) in Poland. Biodiversity: Research and Conservation 1-2:69-76.

atcheva, R. \& A. Ganeva 2005. Check-list of the bryophytes of Bulgaria. II. Musci. Cryptogamica Bryologica 26:149_ 172.

Notov, A.A., U.N. Spirina, E.A. Ignatova \& M.S. Ignatov 2002. Mosses of the Tver Province (Middle Part of European Russia). Arctoa 11:297-332 (in Russian with English summary). [Нотов А.А., Спирина У.Н., Игнатова Е.А., Игнатов М.С. 2002. Аистостебельные мхи Тверской области (Средняя полоса Европейской России) // Arctoa. T. 11. C. 297-332].

Papp, B., P. Erzberger, P. Odor, Zs. Hock, P. Szoveyi, E. Szurdoki \& Z. Toth 2010. Updated checklist and red list of Hungarian Bryophytes. Studia botanica hungarica 41: 31-59.

Partyka, L.Ya. 2005. The bryoflora of Crimea. Fitosociocentr, Kiev, 170 pp. (in Russian). [Партыка А.Я. 2005. Бриофлора Крыма. Киев: Фитосоциоцентр. 170 с.].

Phillips, S.J, R.P. Anderson \& R.P. Schapire 2006 Maximum entropy modeling of species geographic distributions. Ecological Modelling 190:231-259.

Pisarenko, O.Yu. \& V.A. Bakalin 2017. Moss diversity distribution patterns and agglomerates of local floras in the Russian Far East. Botanica Pacifica 6(2): 21-33.

Popov, S.Yu. 2000. Flora of peat mosses of Zhiguli State Reserve. In: Biodiversity of protected areas: estimate, conservation, monitoring, pp. 194-196, Moscow, Samara (in Russian). [Попов С.Ю. 2000. ФАора сфагновых мхов Жигулёвского заповедника // Биологическое разнообразие заповедных территорий: оценка, охрана, мониторинг. M., Самара. С. 194-196].

Popov, S.Yu. 2016. The climatic patterning of Sphagnum sect. Sphagnum species distribution in the East European Plain. Arctoa 25(2):332-352.

Popov, S.Yu. 2017. Modeling the species distribution range based on the geostatistical techniques (on example of Sphagnum mosses). Trudy Karel'skogo Nauchnogo Tsentra 6:7083 (in Russian with English summary). [Попов С.Ю. 2017. Использование методов геостатистики Аля моАелирования ареалов видов (на примере видов рода Sphagnum) // Труды КарНЦ. Сер. Биогеография. № 6. C. 70-83].

Popov, S.Yu. \& N.N. Buryanina 2012. Ecological features of Sphagnum mosses in the Northern taiga. In: Long-term dynamics of ecosystem components of the natural complex of the Pinezhsky nature reserve and adjacent areas, pp. 51-63, GPZ «Pinezhsky», Arkhangelsk (in Russian). [Попов С.Ю., Бурянина Н.Н. 2012. Особенности экологии сфрагновых мхов в северной тайге // Многолетняя динамика компонентов экосистем природного комплекса Пинежского заповедника и сопредельных территорий. Архангельск: ГПЗ “Пинежский”. С. 51-63]. 
Popov, S.Yu. \& V.E. Fedosov 2017. Coenotic distribution and ecological preferences of Sphagnum mosses in Northern Taiga, European Russia (Pinega State Reserve, Arkhangelsk Province). Trudy Karel'skogo Nauchnogo Tsentra 9: 3-29 (in Russian with English summary). Попов С.Ю., Федосов В.Э. Ценотическое распределение и экологические предпочтения сфагновых мхов (Sphagnaceae) в северной тайге Европейской России (Пинежский заповеАник, Архангельская область) // Труды КарНЦ. Сер. Экологические исследования. 2017, № 9. С. 3-29].

Popov, S.Yu., V.E. Fedosov, S.A. Moshkovsky \& M.S. Ignatov 2004. Moss flora of Kerzhensky State Reserve (Nizhnii Novgorod Province, European Russia). Arctoa 13:5766 (in Russian with English summary). [Попов С.Ю., Федосов В.Э., Мошковский С.А., Игнатов М.С. 2004. ФАора мхов Керженского заповедника (Нижегородская область, Европейская часть России) // Arctoa. T. 13. C. 57-66].

Popov, S.Yu., S.A. Moshkovsky, K.I. Belovezhets, T.S. Chupalenkova, N.L. Mel'nichenko \& M.S. Ignatov 2001. Contribution for the bryophyte expedition to Prisursky Nature State Reserve. Ecologicheskiy Vestnik Chuvashskoi Respubliki 25:29-34 (in Russian). [Попов С.Ю., Мошковский С.А., Беловежец К.И., Чупаленкова Т.С., Мельниченко Н.А., Игнатов М.С. 2001. Материалы по бриологической экспедиции по государственному природному заповеднику "Присурский” / / Экологический вестник Чувашской респуб์лики. Т. 25. С. 29-34].

Popova, N.N. 2002. Bryoflora of the Central Russian Uppland. I. Arctoa 11:101-168 (in Russian with English summary). [Попова Н.Н. 2002. Бриофлора Среднерусской возвышенности. I // Arctoa. T. 11. C. 101-168].

Popova, N.N., V.V. Teleganova \& M.A. Boychuk 2015. Bryoflora of the Memorial and Nature Museum-Reserve "Kulikovo pole" (Tula Province, Middle European Russia). Arctoa 24(2):567-573 (in Russian with English summary). [Попова Н.Н., Телеганова В.В., Бойчук М.А. 2015. Бриофлора Государственного военно-исторического и природного музея-заповедника "Куликово Поле" (Тульская область, Средняя часть Европейской части России) // Arctoa. Т. 24. С. 567-573].

Privitera, M., M. Aleffi, G. Bertani, P. Campisi, A. Carratello, M. Codogno, A. Cogoni et al. 2010. Survey of the bryophyte diversity of the Carnic Alps, including some interesting records for the Italian bryoflora. Flora Mediterrania 20:193-209.

Puzachenko, Yu.G., S.L. Kuz'min \& R.B. Sandlerskii 2011. Quantitative estimation of area parameters (with representatives of the genus Rana as a case study). Zhurnal obshchei biologii 72(5):339-354 (in Russian with English summary). [Пузаченко Ю.Г., Кузьмин С.А., Сандмерский Р.Б. 2011. Количественная оценка параметров ареалов (на примере представителей рода Rana) // Журнал общей биологии. Т. 72, № 5. С. 339-354].

Rubtsova, A.V. 2005. Bryoflora of Udmurt Republic. In: Actual problems of bryology, pp. 171-177, NC RAN, S.-Petersburg (in Russian). Руббцова А.В. 2005. Бриофлора УАмуртской респуб์лики // Актуальные проб̆лемы бриологии. СПб.: НЦ РАН. С. 171-177].

Rykovsky, G.F. \& O.M. Maslovsky 2009. The Flora of Belarus. Bryophytes. 1. Andraeopsida-Bryopsida. Belaruska nauka, Minsk. 437 pp. (in Russian). Рыковский Г.Ф., Масловский О.М. 2009. ФАора Беларуси. Мохообразные. T. 1. Andraeopsida-Bryopsida. Минск: Бемаруская наука. 437 c.].

Sabovljević, M., R. Natcheva, G. Dihoru, E. Tsakiri, S. Dragićević, A. Erdağ \& B. Papp 2008. Check-list of the mosses of SE Europe. Phytologia Balcanica 14(2):207-244.
Savel'ev, A.A., S.S. Mukharamova, A.G. Pilyugin \& N.A. Chizhikova 2012. Geostatistical data analysis in ecology and nature management (using the $\mathrm{R}$ package). Kazanskii universitet, Kazan'. 120 рр. (in Russian). [Савельев А.A., Мухарамова С.С., Пилюгин А.Г., Чижикова Н.А. 2012. Геостатистический анализ данных в экологии и природопользовании (с применением пакета R). Казань: Казанский университет. 120 с.].

Séneca, A. \& L. Söderström 2008. Species richness and distribution ranges of European Sphagnum. Folia Cryptogamica Estonica 44:125-130.

Serebryakova, N.N. 2009. Ecological and biological features of mosses and their use in environmental monitoring. PhD Thesis, Saratov, 128 pp. (in Russian). [Серебрякова Н.H. 2009. Эколого-биологические особенности мистостебельных мхов и использование их в экологическом мониторинге. Аисс... канд.биол.наук. 03.00.05; 03.00.16. Саратов. 128 с.].

Sereda, V.A. \& M.S. Ignatov 2008. Bryoflora of Nothern Azov area (Rostov-On-Don Province, European Russia). Arctoa 17:185-190.

Sergioa, C., R. Figueirab, D. Drapera, R. Menezesb \& A.J. Sousab 2007. Modelling bryophyte distribution based on ecological information for extent of occurrence assessment. Biological Conservation 135:341-351.

Shelford, V.E. 1931. Some concepts of bioecology. Ecology 12(3):455-467.

Shestakova, A.A. 2005. Organization of bryobiota in Niz̧hniy Novgorod Region: Ecologo-coenotical and floristical features. PhD Thesis. Nizhniy Novgorod. 223 pp. (in Russian). Шестакова А.А. 2005. Эколого-ценотические и фмористические особенности организации бриобиоты на территории Нижегородской области. Аиссер. ... канд. биол. наук. Н.-Новгород. 223 с.].

Shlyakov, R.N. \& N.A. Konstantinova 1982. Check-list of mosses of Murmansk Province. Kol'skiy filial AN SSSR, Apatity. 227 pp. (in Russian). Шияков Р.Н., Константинова Н.А. 1982. Конспект фморы мохообразных Мурманской обмасти. Апатиты: Кольский филиал АН СССР. 227 с.].

Shmidt, V.M. 1979. Dependence of local flora's quantitative indicators of the European part of the USSR on geographical latitude. Botanicheskii Zhurnal 62(2):172-183 (in Russian). [Шмилт B.M. 1979. Зависимость количественных показателей конкретных флор Европейской части СССР от географической широты // Ботанический журнал. Т. 62, № 2. С. 172-183].

Simonov, G.P. 1978. Handbook of mosses of Moldavian SSR. Shtiinza, Kishinev. 168 pp. (in Russian). [Симонов Г.П. 1978. Определитель мистостебельных мхов Молдавской ССР. Кишинев: Штиинца. 168 с.].

Smagin, V.A., M.G. Noskova, V.K. Antipin \& M.A. Boichuk 2017. Diversity and phytosociological role of mosses in mires of southwestern Arkhangelsk Region and adjacent territories. Trudy Karel'skogo Nauchnogo Tsentra 1:7596 (in Russian with English summary). [Смагин B.A., Носкова М.Г., Антипин В.К., Бойчук М.А. 2017. Разнообразие и фитоценотическая роль мхов на болотах юго-запада Архангельской области и сопредельных территорий // Труды КарНЦ. № 1. С. 75-96].

Söderström, L. (ed.) 1998. Preliminary distribution maps of bryophytes in Northwestern Europe, vol. 3 (Musci J-Z). Mossornas Vónnar, Trondheim. $72 \mathrm{pp}$.

Spirina, U.N. \& V.I. Zolotov 2004. Mosses of the Orenburg State Nature Reserve (South-Eastern European Russia). Arctoa 13:51-56 (in Russian with English summary). [Спирина У.Н., Золотов В.И. 2004. Мхи Оренбургского государственного природного заповедника 
(юго-восток Европейской части России) // Arctoa T. 13. C. 51-56].

Stebel, A. 2012. Preliminary studies on the bryoflora of Narwianski National Park (NE Poland). The Journal of Silezian Museum in Opava 61:265-271.

Strazdina, L., L. Madžule \& G. Brümelis 2011. A contribution to the bryoflora of Moricsala island Nature Reserve, Latvia. Folia Cryptogamica Estonica 48:107-117.

Suragina, S.A. 2001. Mosses of the Volgograd Province (South-Eastern European Russia). Arctoa 10:45-70 (in Russian with English summary). [Сурагина С.А. 2001. Аистостебельные мхи Волгоградской области (Юго-Восток Европейской России) // Arctoa. T. 10. С. 45-70].

Suragina, S.A., E.A. Ignatova \& M.S. Ignatov 2002. Contribution to the moss flora of Astrakhan Province (South European Russia). Arctoa 10:169-174 (in Russian with English summary). [Сурагина С.А., Игнатова Е.А., Игнатов М.С. 2002. Материалы к флоре мхов Астраханской области (юг Европейской России) // Arctoa. T. 11. C. 169-174].

Teleganova, V.V. 2008. Mosses of Kaluga (Middle European Russia) and their reproductive features. Arctoa 17: 169-184.

Tolmachev, A.I. 1974. Introduction in plant geography. Izdatel'stvo Leningradskogo universiteta, Leningrad. 243 pp. (in Russian). [Толмачев А.И. 1974. Введение в географию растений. $\Lambda .:$ Издательство ИенинграАского университета. 243 с.].

Vellak, K., N. Ingerpuu, M. Leis \& L. Ehrlich 2015. Annotated check-list of Estonian bryophytes. Folia Cryptogamica Estonica 52:109-127.

Volkova, L.A., A.L. Zhukova, A.D. Potemkin \& N.D. Nemceva 1994. Bryophytes of Darvin State Reserve. In: Flora and vegetation of the Tver Province, pp. 13-24, Tverskoi gosudarstvennyi universitet, Tver (in Russian). ВВолкова $\Lambda . A$., Жукова А.А., Потемкин А.А., Немцева Н.А. 1994. Мохообразные Аарвинского государственного заповедника / / ФАора и растительность Тверской области. Тверь: Тверской государственный университет. С. 13-24].

Volosnova, L.F., E.A. Ignatova \& M.S. Ignatov 2000. Bryophyte flora of Oksky Nature Reserve (European Russia, Ryazan
Province). Arctoa 9:3-11 (in Russian with English summary). [Волоснова А.Ф., Игнатова Е.А., Игнатов М.С. 2000. Бриофлора Окского заповедника (Европейская Россия, Рязанская область) // Arctoa. T. 9. С. 3-11].

Wojtun B., A. Sendyk \& D. Martyniak 2013. Sphagnum species along envinronmental gradients in mires of the Sudety Montains (SW Poland). Boreal Environment Research 18:74-88.

Woodward, F.I. 1987. Climate and plant distribution. Cambridge University Press, Cambridge. 188 pp.

Zerov, D.K. \& L.Ya. Partyka 1975. The bryophytes of Ukrainian Carpathians. Naukova dumka, Kiev. 230 pp. (in Ukrainian). [Зеров А.К., Партика А.Я. 1975. Мохоподібні Украінских Карпат. Киів: Наукова Аумка. 230 с.].

Zheleznova, G.V. 1994. The moss flora of the European Northeast. Nauka, Saint-Petersburg. 149 pp. (in Russian). [Жeлезнова Г.В. 1994. ФАора листостебельных мхов Европейского Северо-Востока. Спб.: Наука. 149 с.].

Zheleznova, G.V. 2014. On the moss flora of Kirov Province. Arctoa 23:212-218 (in Russian with English summary). [Железнова Г.В. 2014. К флоре листостебельных мхов Кировской области // Arctoa. Т. 23. С. 212-218].

Zheleznova, G.V. \& T.P. Shubina 1997. Bryoflora of the Pechora-Ilych Biosphere Reserve. In: Flora and vegetation of the Pechora-Ilych Biosphere Reserve, pp. 175-210. UrO RAN, Ekaterinburg (in Russian). [Железнова Г.В., Шубина Т.П. 1997. Бриофлора Печоро-Илычского биосферного заповедника // ФАора и растительность Печоро-Илычского биосферного заповедника. Екатеринбург: УрО РАН. С. 175-210].

Zheleznova, G.V. \& T.P. Shubina 2015. Mosses of the Belaya River Basin (Nothern Timan, Nenets Autonomous District). Arctoa 24:204-209.

Zolotov, V.I. \& E.Z. Baisheva 2003. Moss flora of "Shulgan-Tash" Nature Reserve (Republic Bashkortostan, Russia). Arctoa 12:121-132 (in Russian with English summary). [Золотов В.И., Баишева Э.З. 2003. Фмора мистостебельных мхов заповедника "Шульган-Таш" (Республика Башкортостан, Россия) // Arctoa. Т. 12. C. 121-132]. 